\title{
Cytotoxicity-Related Bioeffects Induced by Nanoparticles: The Role of Surface Chemistry
}

\author{
Hainan Sun ${ }^{1,2}$, Cuijuan Jiang ${ }^{3}$, Ling Wu ${ }^{1}$, Xue Bai ${ }^{1}$ and Shumei Zhai ${ }^{1 *}$ \\ ${ }^{1}$ Key Laboratory of Colloid and Interface Chemistry of the Ministry of Education, School of Chemistry and Chemical \\ Engineering, Shandong University, Jinan, China, ${ }^{2}$ Shandong Vocational College of Light Industry, Zibo, China, ${ }^{3}$ School of \\ Environmental Science and Engineering, Shandong University, Qingdao, China
}

\section{OPEN ACCESS}

Edited by:

Gaoxing Su,

Nantong University, China

Reviewed by:

Liwen Li,

Indiana University, United States

Qingxin Mu

University of Washington,

United States

Wenting Zhao,

Nanyang Technological

University, Singapore

*Correspondence:

Shumei Zhai

smzhai@sdu.edu.cn

Specialty section:

This article was submitted to

Nanobiotechnology,

a section of the journal

Frontiers in Bioengineering and

Biotechnology

Received: 13 October 2019 Accepted: 28 November 2019

Published: 12 December 2019

Citation:

Sun H, Jiang C, Wu L, Bai $X$ and

Zhai S (2019) Cytotoxicity-Related

Bioeffects Induced by Nanoparticles:

The Role of Surface Chemistry.

Front. Bioeng. Biotechnol. 7:414.

doi: 10.3389/fbioe.2019.00414
Nanoparticles (NPs) are widely used in a variety of fields, including those related to consumer products, architecture, energy, and biomedicine. Once they enter the human body, NPs contact proteins in the blood and interact with cells in organs, which may induce cytotoxicity. Among the various factors of NP surface chemistry, surface charges, hydrophobicity levels and combinatorial decorations are found to play key roles inregulating typical cytotoxicity-related bioeffects, including protein binding, cellular uptake, oxidative stress, autophagy, inflammation, and apoptosis. In this review, we summarize the recent progress made in directing the levels and molecular pathways of these cytotoxicity-related effects by the purposeful design of NP surface charge, hydrophobicity, and combinatorial decorations.

Keywords: nanoparticles, surface chemistry, charge, hydrophobicity, PEG, cytotoxicity

\section{INTRODUCTION}

Due to their unique physicochemical properties, nanoparticles (NPs) with various compositions (metals, metal oxides, semiconductors, and organic molecules) are widely used in various materials, including those in the consumer product, architecture, energy, and biomedicine fields (De Volder et al., 2013; Peng et al., 2014; Lane et al., 2015; Chen et al., 2016). NPs may enter the human body through oral administration, implantation, intravenous injection, transdermal absorption, etc., eliciting public concerns about the adverse effects of NPs (Zhang et al., 2014). Once entering the human blood circulation system, NPs spontaneously adsorb proteins, which reduce their surface free energy (Cedervall et al., 2007; Lundqvist et al., 2008; Monopoli et al., 2012; Su et al., 2016). Moreover, NPs can interact with the cell membrane (Lin et al., 2010; Jing and Zhu, 2011; Lesniak et al., 2013), lipids (Leroueil et al., 2008), proteins (Mahmoudi et al., 2011), and DNA (Asharani et al., 2009; Xie J. et al., 2019), eliciting various bioeffects, such as the disruption of the cell membrane, oxidative stress, apoptosis, inflammation, and autophagy, which may ultimately lead to cytotoxicity. Elucidation of NP-induced cytotoxicity is crucial for human health.

Interactions between NPs and biosystems are critically determined by surface chemistry. Surface modification of NPs may be made during the synthesis process or environmental exposure (Bystrzejewska-Piotrowska et al., 2009; Wang et al., 2013). For example, charged ligands such as cetyl trimethyl ammonium bromide $(\mathrm{CTAB})$ and citrate acid are frequently used as protective agents in NP synthesis processes (Nikoobakht and El-Sayed, 2003; Lim et al., 2009). Surface decorations can regulate the physicochemical properties of NPs to ultimately affect their various biological effects. For example, a decoration comprising positively charged and hydrophobic 
ligands on NPs can enhance the cellular uptake level ( $\mathrm{Su}$ et al., 2012; Li et al., 2015a). A decoration consisting of poly(ethylene glycol) (PEG) can reduce protein binding in the blood and avoid recognition by the reticular endothelial system (RES) (Zhang T. et al., 2019). Moreover, surface chemistry is one of the key factors that can trigger adverse effects in biosystems. The role of surface functionality in determining nanobiological interactions has been well reviewed in some excellent recent literature (Verma and Stellacci, 2010; Albanese et al., 2012; Kim et al., 2013; Nam et al., 2013; Zhu et al., 2013). To establish a distinct relationship between the surface chemistry of NPs and cytotoxicity, in this review, we systematically summarize our research and that of others on the latest progress in understanding the impact of typical surface chemistry, including surface charge, hydrophobicity, and combinatorial decorations, on various cytotoxicity-related bioeffects, including protein binding, cellular uptake, oxidative stress, autophagy, inflammation, and apoptosis. The surface chemistry driver of bioeffect levels and molecular pathways is discussed in detail. These findings may be used to predict adverse cellular responses of NPs and guide the design of environmentally safe NPs, including medical NPs that could potentially be used in the treatment of diseases.

\section{PROTEIN BINDING}

NPs can enter the human body through multiple pathways and be distributed to different organs through circulating blood. In blood, NPs progressively and selectively adsorb proteins and form protein coronas that reduce their surface free energy. According to binding strength and relative position, a protein corona can be divided into a hard part and a soft part. The hard corona binds to the surface of the NP tightly, where it forms a near-monolayer. The soft corona is formed over top of the hard corona, and the interactions between the soft corona and NPs are weak (Monopoli et al., 2012). The protein corona on NPs can be analyzed by atomic force microscope images, fluorescence spectroscopy, circular dichroism, sodium dodecyl sulfate-polyacrylamide gel electrophoresis (SDS-PAGE), and mass spectrometry (Cedervall et al., 2007; Ge et al., 2011).

The formation of protein corona can result in undesired cellular uptake, nanoparticle aggregation, or immune responses (Karmali and Simberg, 2011). However, it can also alleviate cytotoxicity. For example, in THP-1 and human umbilical vein endothelial cells (HUVECs), the adsorption of bovine fibrinogen, bovine serum albumin (BSA), transferrin, or gamma globulin formed compact layers on NPs' surface, which effectively shield cells from the exposure of NPs' surfaces and alleviate the cytotoxicity induced by single-walled carbon nanotubes (SWCNTs) (Ge et al., 2011). In another study, serum protein adsorption significantly reduced the cytotoxicity of graphene oxide (GO) in A549 cells (Hu et al., 2011). In addition, protein binding can drastically alter the physicochemical properties of NPs and affect their behavior in vivo (Albanese et al., 2012).

In this section, we summarize recently published literatures related to the regulation of protein binding by NPs' surface charge, hydrophobicity, and combinatorial surface modifications
(Table 1), which are generally considered as important factors that characterize NPs' surface coating.

\section{Surface Charge}

Compared to neutral NPs, charged NPs tend to adsorb more proteins from serum. For example, poly $(\mathrm{N}-(2-$ aminoethyl)acrylamide) and poly(acrylic acid)-decorated gold nanoparticles (GNPs, 5-20 nm), which exhibit positive and negative charge, respectively, adsorbed large amounts of plasma proteins; however, relatively few proteins adsorbed onto neutrally charged poly(N-(2,3-dihydroxypropyl)acrylamide)-GNPs (Deng et al., 2012).

Regarding charged NPs, positive and negative charges exhibit different protein binding capacities. For example, silica NPs $(50 \mathrm{~nm})$ decorated with amine or carboxyl groups exhibited different protein binding levels, with the negatively charged silica NPs adsorbing more proteins from human serum than were adsorbed by their positively charged counterparts (Kurtz-Chalot et al., 2017). In another study, it was also found that polystyrene (PS) NPs $(140 \mathrm{~nm})$ decorated with carboxyl or amine group exhibited different binding capacities to human serum protein. The total number of corona proteins on carboxyl-decorated PS NPs was higher than the number on their amine-decorated counterparts (Kokkinopoulou et al., 2017). The surface charge of silica NPs $(100 \mathrm{~nm})$ affected the recruitment of transforming growth factor (TGF)- $\beta 1$ to the NP surface. Positively charged aminated- and polyetherimide (PEI)-silica NPs completely failed to adsorb TGF- $\beta 1$ in a mouse lung tissue homogenate supernatant, while negatively charged hydrogenated, dextransilica, and gelatin-silica NPs largely adsorbed TGF- $\beta 1$ (Wang et al., 2017). The surface charge of nanodiamonds $(5 \mathrm{~nm})$ could regulate protein binding speed. The adsorption rate of BSA on negatively charged nanodiamonds is higher than the rate on positively charged counterparts (Aramesh et al., 2015). Therefore, negatively charged NPs are more liable to adsorb proteins compared to positively charged NPs.

For NPs with a negative charge, the protein binding could also be tuned by other factors, including charge densities and ligand species. For example, libraries of silica NPs $(170 \pm$ $20 \mathrm{~nm}$ ) with continuously changing surface charge densities were synthesized by tuning the surface density of negatively charged succinic anhydride ligand. The overall amounts of serum protein, BSA, and apolipoprotein 1 adsorbed onto silica NPs decreased with the increase in negative charge density (Beck et al., 2017). Both sulfonated and carboxylated PS NPs (50 nm) have negatively charged surfaces. Although the composition of the protein corona isolated from these PS NPs was the same, some proteins, including A2M, AFP, APOA2, APOH, and HBB were significantly less adsorbed onto the sulfonated PS NPs (Abdelkhaliq et al., 2018). In another study, it was found that negatively charged poly(methacrylic acid)-decorated iron oxide NPs $(10 \mathrm{~nm})$ tended to adsorb more proteins from fetal bovine serum (FBS) than were adsorbed by citric acid-decorated iron oxide NPs (Mekseriwattana et al., 2019).

In addition to protein levels, surface charge could also define the protein species adsorbed onto NPs. For example, more total and complement protein species were adsorbed on 
TABLE 1 | Protein binding regulated by NPs' surface chemistry.

\begin{tabular}{|c|c|c|c|c|}
\hline Composition & Size & Surface chemistry/Zeta potential/LogP & Protein binding capacity & References \\
\hline Gold & $5-20 \mathrm{~nm}$ & $\begin{array}{l}\text { Poly(N-(2-aminoethyl) acrylamide) (PAEA, 46- } \\
57 \mathrm{mV}) \\
\text { poly(acrylic acid) (PAA, -25 to -60 mV), } \\
\text { poly(N-(2,3-dihydroxypropyl)acrylamide) } \\
\text { (PDHA, slightly negatively charged) }\end{array}$ & $\mathrm{PAEA}>\mathrm{PAA}>\mathrm{PDHA}$ & Deng et al., 2012 \\
\hline Gold & $17 \mathrm{~nm}$ & Methoxy-PEG-alkyl-thiol, methoxy-PEG-thiol & $\begin{array}{l}\text { Methoxy-PEG-thiol>methoxy- } \\
\text { PEG-alkyl-thiol }\end{array}$ & Larson et al., 2012 \\
\hline Gold & $14-22 \mathrm{~nm}$ & $\begin{array}{l}\text { Mercaptosuccinic acid, N-4-thiobutyroil } \\
\text { glucosamine, } \text { PEG }_{5000} \text { and alkyl-PEG } 600\end{array}$ & $\begin{array}{l}\text { (Mercaptosuccinic acid and } \\
\text { N-4-thiobutyroil } \\
\text { glucosamine) }>\left(\text { PEG }_{5000} \text { and }\right. \\
\text { alkyl-PEG } 600)\end{array}$ & Silvestri et al., 2017 \\
\hline Gold & $5 \mathrm{~nm}$ & $\begin{array}{l}\text { PEG, citric-, phosphine-, } \\
\text { poly(isobutylene-alt-maleic anhydride) }\end{array}$ & $\begin{array}{l}\text { [Citric-, phosphine-, } \\
\text { poly(isobutylene-alt-maleic } \\
\text { anhydride)]>PEG }\end{array}$ & $\begin{array}{l}\text { Johnston et al., } \\
2017\end{array}$ \\
\hline Gold & $13 \mathrm{~nm}$ & PEG $(-13.5 \mathrm{mV})$, tannic acid $(-28.1 \mathrm{mV})$ & Tannic acid>PEG & Braun et al., 2016 \\
\hline Gold & $15,30,60,90 \mathrm{~nm}$ & PEG (5 kDa) & $\begin{array}{l}\text { Negatively correlated with } \\
\text { PEG density }\end{array}$ & Walkey et al., 2012 \\
\hline Gold & $45 \mathrm{~nm}$ & PEG $(2,5,10,20 \mathrm{kDa}),-5.4 \mathrm{mV}$ to $-25.4 \mathrm{mV}$ & $\begin{array}{l}\text { Positively correlated with PEG } \\
\text { chain length }\end{array}$ & Su et al., 2018 \\
\hline Silver & $30 \mathrm{~nm}$ & $\begin{array}{l}\text { PEG }(-16.2 \mathrm{mV}) \text {, citrate }(-22.9 \mathrm{mV}) \\
\text { polyvinylpyrrolidone }(-22.1 \mathrm{mV})\end{array}$ & $\begin{array}{l}\text { (Citrate, } \\
\text { polyvinylpyrrolidone)>PEG }\end{array}$ & Pang et al., 2016 \\
\hline Silica & $50 \mathrm{~nm}$ & $\mathrm{COOH}(-42 \mathrm{mV}), \mathrm{NH}_{2}(25 \mathrm{mV})$ & $\mathrm{COOH}>\mathrm{NH}_{2}$ & $\begin{array}{l}\text { Kurtz-Chalot et al., } \\
2017\end{array}$ \\
\hline Silica & $100 \mathrm{~nm}$ & $\begin{array}{l}\text { Hydration }(-34.63 \mathrm{mV}) \text {, dextran }(-17.54 \mathrm{mV}) \text {, } \\
\text { gelatin }(-23.52 \mathrm{mV}) \text {, amination }(14.91 \mathrm{mV}) \text {, PEl } \\
(15.84 \mathrm{mV})\end{array}$ & $\begin{array}{l}\text { (Hydration, dextran, } \\
\text { gelatin) }>\text { (amination, PEI) }\end{array}$ & Wang et al., 2017 \\
\hline Silica & $170 \mathrm{~nm}$ & Succinic anhydride $(-5 \mathrm{mV}$ to $-40 \mathrm{mV})$ & $\begin{array}{l}\text { Decreased with the increase } \\
\text { in negative charge density }\end{array}$ & Beck et al., 2017 \\
\hline Iron oxide & $10 \mathrm{~nm}$ & Methacrylic acid, citric acid & Methacrylic acid > citric acid & $\begin{array}{l}\text { Mekseriwattana } \\
\text { et al., } 2019\end{array}$ \\
\hline Iron oxide & $12 \mathrm{~nm}$ & Glucose, PEG & Glucose $>$ PEG & Stepien et al., 2018 \\
\hline $\mathrm{ZnO}$ & $39 \mathrm{~nm}$ & PEG $(10 \mathrm{mV})$, bare $(30 \mathrm{mV})$ & Bare $>$ PEG & Luo et al., 2014 \\
\hline SWCNTS & Diameter: 6-8 nm & $\begin{array}{l}\mathrm{COOH} \text { (hydrophilic, }-23.27 \mathrm{mV} \text { ), } \mathrm{CH}_{3} \\
\text { (hydrophobic, } 12.63 \mathrm{mV} \text { ) }\end{array}$ & $\mathrm{COOH}>\mathrm{CH}_{3}$ & Li et al., 2013 \\
\hline MWCNTS & $\begin{array}{l}\text { Diameter: } 10-20 \mathrm{~nm} \text {, } \\
\text { length: } 5-15 \mu \mathrm{m}\end{array}$ & Pristine (-14.97 mV), PEG (-15.60 mV) & Pristine $>$ PEG & Zhang T. et al., 2019 \\
\hline Nanodiamonds & $5 \mathrm{~nm}$ & $\begin{array}{l}\text { Hydrogen-terminated }(49 \mathrm{mV}) \\
\text { oxygen-terminated }(-51 \mathrm{mV})\end{array}$ & $\begin{array}{l}\text { Oxygen-terminated }> \\
\text { hydrogen-terminated }\end{array}$ & Aramesh et al., 2015 \\
\hline Polystyene & $140 \mathrm{~nm}$ & $\mathrm{COOH}(-7.21 \mathrm{mV}), \mathrm{NH}_{2}(7.58 \mathrm{mV})$ & $\mathrm{COOH}>\mathrm{NH}_{2}$ & $\begin{array}{l}\text { Kokkinopoulou } \\
\text { et al., } 2017\end{array}$ \\
\hline Polystyrene & $50 \mathrm{~nm}$ & $\begin{array}{l}\text { Sulfonated }(-13.3 \mathrm{mV}) \text {, carboxylated } \\
(-10.2 \mathrm{mV})\end{array}$ & Carboxylated > sulfonated & $\begin{array}{l}\text { Abdelkhaliq et al., } \\
2018\end{array}$ \\
\hline $\begin{array}{l}\mathrm{N} \text {-isopropylacrylamide- } \\
\text { co-N-tert-butylacrylamide } \\
\text { copolymer }\end{array}$ & $70 \mathrm{~nm}$ & $\begin{array}{l}\text { NIPAM:BAM=85:15 (more hydrophilic), 65:35, } \\
\text { and 50:50 (more hydrophobic) }\end{array}$ & $50: 50>65: 35>85: 15$ & $\begin{array}{l}\text { Cedervall et al., } \\
2007\end{array}$ \\
\hline
\end{tabular}

positively charged silica NPs $(50 \mathrm{~nm})$ than were adsorbed on their negatively charged counterparts (Kurtz-Chalot et al., 2017). In another study, the protein binding of amine-functionalized and bare PS NPs $(100 \mathrm{~nm})$ was compared. The proteins adsorbed on the positively charged PS NPs were more hydrophobic than those adsorbed on the bare PS NPs (Kendall et al., 2015). For pristine, amine-modified and carboxyl-modified silica NPs $(22.4 \pm 2.2 \mathrm{~nm})$, the surface charge affects the adsorption of the proteins species related to immune responses, transport, regulation of proteolysis, hyaluronan metabolic processes, and other functions (Mortensen et al., 2013). Citric acid, poly(acrylic acid), and oleic acid decorations all endow iron oxide NPs with a negative charge; however, the protein corona composition and structure were influenced by these three kinds of surface decoration (Jedlovszky-Hajdú et al., 2012).

\section{Hydrophobicity}

Cedervall et al. (2007) used a series of copolymer NPs to investigate the impact of NP hydrophobicity on protein binding. They found that the number of protein molecules adsorbed 


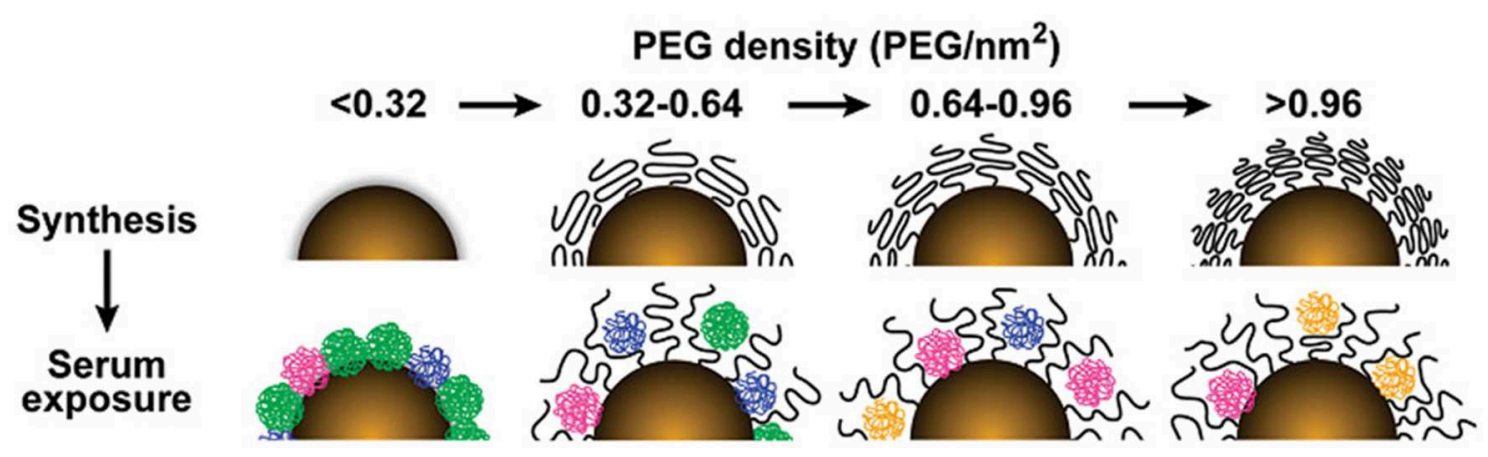

FIGURE 1 | The influence of PEG density on serum protein adsorption to gold nanoparticles. The top panel shows as-synthesized gold nanoparticles grafted with PEG at increasing density. As PEG density increases, PEG volume decreases as a result of PEG-PEG steric interactions. The lower panel illustrates how PEG density determines the amount and relative abundance of serum proteins adsorbed to the gold nanoparticle surface after serum exposure. Adapted with permission from Walkey et al. (2012).

onto NPs increased with NP hydrophobicity. However, in other papers, an opposite conclusion was drawn. For example, hydrophilic $\mathrm{COOH}$ - and hydrophobic $\mathrm{CH}_{3}$-SWCNTs exhibited different affinities for recombinant human bone morphogenetic protein-2 (rhBMP-2). The amount of rhBMP-2 adsorbed onto the $\mathrm{COOH}-\mathrm{SWCNT}$ was higher than the amount adsorbed onto the $\mathrm{CH}_{3}$-SWCNTs (Li et al., 2013). In another study, incorporating an alkyl linker between the PEG and thiol moieties enhanced the hydrophobicity of the ligands, which resulted in a decrease in protein binding onto GNPs (17 nm) (Larson et al., 2012).

Due to the presence of hydrophilic group, such as ether bond in the middle of the polymer chain and hydroxyl at the end, PEG modification on NPs could reduce surface hydrophobicity (Kleemann et al., 2005; Sheng et al., 2009; Xiong et al., 2012; Jiang et al., 2016). PEG decoration on GNPs and silver NPs leads to lower protein binding compared to other decorations. For example, compared to mercaptosuccinic acid and N-4thiobutyroil glucosamine, $\mathrm{PEG}_{5000}$ and alkyl-PEG 600 decorations on GNPs (14-22 nm) induced lower levels of protein adsorption from FBS (Silvestri et al., 2017). In another comparative study, PEG-GNPs $(5 \mathrm{~nm})$ were found to adsorb fewer proteins than were adsorbed by citric-, phosphine-, or poly(isobutylene-altmaleic anhydride)-GNPs (Johnston et al., 2017). Moreover, PEG decoration on GNPs $(13 \mathrm{~nm})$ was also found to bind fewer proteins than were bound by the tannic acid decoration (Braun et al., 2016). For silver NPs (30 nm), PEG decoration led to lower adsorption of BSA than was adsorbed by citrate and polyvinylpyrrolidone decorations (Pang et al., 2016).

The PEG density and length can tune protein binding on GNPs. For GNPs of four different sizes $(15,30,60,90 \mathrm{~nm})$, the total serum protein adsorption was negatively correlated with PEG density (Figure 1) (Walkey et al., 2012). Furthermore, as the molecular weight of the PEG decoration increased from 2 to $20 \mathrm{~K}$, the amount of adsorbed protein on the GNPs ( $45 \mathrm{~nm})$ showed an increasing trend (Su et al., 2018).

PEG decoration on other NPs can also reduce protein adsorption. For example, PEG decorated $\mathrm{ZnO}$ NPs (39 \pm $4 \mathrm{~nm}$ ) exhibited a lower level of protein adsorption from FBS compared to bare ZnO NPs (Luo et al., 2014). Compared to
NPs with glucose decoration, PEG-iron oxide NPs (12 nm) bound fewer proteins (Stepien et al., 2018). PEG decoration was also found to reduce the adsorption of BSA and IgG compared to pristine multi-walled carbon nanotubes (MWCNTs, with an average diameter of $10-20 \mathrm{~nm}$ and length of 5-15 $\mu \mathrm{m}$ ) (Zhang T. et al., 2019).

\section{Combinatorial Surface Modifications}

Combinatorial chemistry could efficiently afford a vast number of structurally related molecules and materials. The synthesis of surface-modified nanoparticle libraries has been considered as a powerful tool to modulate nanoparticle properties (Zhou et al., 2008). Combining with both experimental and computational methods, the NP libraries could be used to rapidly discover nanoparticles with specific activity and reveal structure-activity relationship at the same time (Gao et al., 2011; Zhou et al., 2011; Wu et al., 2014; Liu Y. et al., 2015; Zhang et al., 2016).

For examples, Zhou et al. synthesized combinatorial libraries of surface-modified MWCNTs and GNPs to investigate the relationships between NP surface chemistry and their ability to bind proteins. They found that surface chemistry could tune the binding affinity of MWCNTs for four typical proteins, namely, BSA, carbonic anhydrase, chymotrypsin, and hemoglobin and for proteins in human plasma and a cell culture medium (Zhou et al., 2008). Furthermore, chemical modifications on the MWCNT surface could perturb the enzymatic activity of CYP3A4 in human liver microsomes by binding to the protein and altering its conformation. Based on a QSAR analysis, Zhang et al. found that long and complex hydrophobic or aromatic side chains on MWCNT surfaces were responsible for inducing the inhibitory effects of f-MWCNTs on CYP3A4, while pharmacophores with lower aromaticity and fewer tertiary nitrogen atoms were more likely to generate safe MWCNTs (Zhang et al., 2016). Moreover, Liu et al. also found that the surface chemistry of the GNPs could dramatically affect both non-specific binding (away from the peripheral site) and specific binding to acetylcholinesterase (AChE), which resulted in the inhibition of the enzyme (Liu Y. et al., 2015). 


\section{CELLULAR UPTAKE}

NPs can enter into cells through multiple pathways, including macropinocytosis and clathrin-, and caveolae-dependent endocytosis et al (Sahay et al., 2010). For macrophages, phagocytosis is the predominant mechanism, while nonprofessional phagocytes, including epithelial cells, fibroblasts, and endothelial cells, may also undertake phagocytosis relatively less frequently (Hillaireau and Couvreur, 2009). Multiple endocytosis inhibitors could be used to distinguish the uptake pathways, including cytochalasin $\mathrm{D}$, methyl- $\beta$-cyclodextrin, nocodazole, etc. (Saha et al., 2013). However, non-specificity and cytotoxicity are inherent disadvantages of these inhibitors. Therefore, multiple inhibitors for a certain pathway are usually used simultaneously, and the dose is carefully chosen.

The cellular uptake level of NPs are usually determined by inductively coupled plasma-mass spectrometry and transmission electron microscopy (TEM) (Su et al., 2012; Saha et al., 2013; Wu et al., 2014; Van Haute et al., 2018). For fluorescent NPs and NPs decorated with fluorescent ligand, the uptake level and subcellular localization can also be analyzed by fluorescence microscope, laser scanning confocal microscopy, and flow cytometry (Zhang et al., 2002; Mahmoud et al., 2010).

The cellular uptake of NPs is strongly associated with various cytotoxicity-related bioeffects, including oxidative stress, apoptosis, autophagy, and inflammation (Xia et al., 2008; Foldbjerg et al., 2011; Stern et al., 2012; Sun et al., 2018). For example, Xia et al found that $\mathrm{ZnO}$ NPs $(13 \mathrm{~nm})$ internalized by RAW264.7 cells elicited oxidative stress, inflammation, and cell death (Xia et al., 2008). In our previous study, cellular uptake level of hydrophobic and positively charged GNPs $(6 \mathrm{~nm})$ was positively correlated with oxidative stress level in A549 cells. Inhibition of GNPs' internalization led to the decrease of oxidative stress level, indicating that oxidative stress induced by GNPs is internalization-dependent (Sun et al., 2018). Therefore, for certain NPs, cellular uptake is positively correlated with cytotoxicity. In this section, we summarize recently published literatures related to the regulation of cellular uptake by NPs' surface charge, hydrophobicity, and combinatorial surface modifications (Table 2).

\section{Surface Charge}

The surface charge of GNPs can tune the cellular uptake level. In primary human dermal microvascular endothelial cells, positively charged ethanediamine-decorated GNPs $(18,35$, and $65 \mathrm{~nm}$ ) were internalized to a greater extent than were neutral or negatively charged GNPs (Freese et al., 2012). In another study, the zeta potential of poly(diallyldimethyl ammonium chloride) (PDDAC), CTAB, and polystyrene sulfonate (PSS)decorated gold nanorods (GNRs) $(33 \times 30$ and $55 \times 14 \mathrm{~nm})$ in aqueous solutions was found to decrease from $\sim 50$ to $-40 \mathrm{mV}$, and the cellular uptake level by these GNRs in MCF7 cells decreased with the decrease in zeta potential (Qiu et al., 2010). Positively charged branched polyethyleneimine-decorated GNPs $(40,80 \mathrm{~nm})$ were more likely than negatively charged lipoic acid-GNPs to be endocytosed by HUVECs (Chandran et al., 2017). In monocytes and macrophages, positively charged
cysteamine-GNPs $(10,20$, and $40 \mathrm{~nm})$ were internalized at a higher level than were negatively charged or zwitterionic GNPs (Oh and Park, 2014). More GNPs (15 and $45 \mathrm{~nm}$ ) decorated with positively charged poly(allyamine hydrochloride) than neutral GNPs were internalized in SK-BR-3 breast cancer cells (Cho et al., 2010). More cationic poly(allylamine hydrochloride)coated GNPs $(20 \mathrm{~nm})$ than anionic GNPs underwent endocytosis in human dermal fibroblast cells (Yang et al., 2014). A library of GNPs $(6 \mathrm{~nm})$ with continuously changing positive charge/negative charge density was constructed by varying the ratio of positively/negatively charged ligands to neutrally charged ligands. In HeLa, HEK293, and A549 cells, Su et al. (2012)and Sun et al. (2018) found that the level of GNP endocytosis was positively correlated with a positive charge density, while negative charge density had no significant influence on cellular uptake (Figure 2). Therefore, in multiple immune and non-immune cells, positively charged GNPs are more prone to endocytosis than are neutral and negatively charged GNPs.

In addition to the cellular uptake level, the surface charge can also tune the endocytosis pathway of GNPs. For example, in HeLa cells, positively charged GNPs (2, 4, and $6 \mathrm{~nm}$ ) were endocytosed through multiple pathways, including the clathrinand caveolae/lipid raft-dependent pathways. Zwitterionic GNPs ( 2 and $4 \mathrm{~nm}$ ) were prone to entering cells through membrane fusion, and zwitterionic GNPs $(6 \mathrm{~nm})$ were endocytosed through the caveolae/lipid raft-mediated pathway. Negatively charged GNPs ( 2 and $4 \mathrm{~nm}$ ) displayed a similar endocytosis pathway to that of positively charged GNPs, while negatively charged GNPs $(6 \mathrm{~nm})$ were internalized through the caveolae/lipid raftmediated pathway (Figure 3) (Jiang et al., 2015). GNRs (aspect ratio $=3$ ) exhibited different endocytosis mechanisms in $\mathrm{HaCaT}$ cells on the basis of their decoration with positively or negatively charged ligands. Positively charged peptide-GNRs were internalized mainly through macropinocytosis and clathrinmediated endocytosis, while negatively charged $\mathrm{COOH}-\mathrm{GNRs}$ were endocytosed through macropinocytosis and caveolaerelated mechanisms (Untener et al., 2013).

The surface charge of oxide NPs can impact the level of their cellular uptake. For example, positively charged $\mathrm{NH}_{2}-\mathrm{TiO}_{2}$ NRs $(50-65 \times 8 \mathrm{~nm})$ were endocytosed by rat bone marrow mesenchymal stem cells at a much higher level than were negatively charged $\mathrm{COOH}-\mathrm{TiO}_{2}$ NRs (Shrestha et al., 2016). $\mathrm{ZnO}$ NPs $(15 \mathrm{~nm})$ decorated with both (1,2-dioleoyl-sn-glycero3 -phosphocholine) (DOPC) and amine-propyl chains exhibited a positive charge in water. However, DOPC-ZnO NPs were internalized at a significantly higher level than were $\mathrm{NH}_{2}-\mathrm{ZnO}$ NPs in HeLa cells, a distinction that may be due to the difference in positive charge (Dumontel et al., 2017). Moreover, the uptake level that is affected by surface charge may vary with cell type. For example, positively charged silica NPs $(20,30,50,80 \mathrm{~nm})$ are more likely to be endocytosed than their pristine or negatively charged counterparts in A549 cells (Ojea-Jiménez et al., 2016); however, in RAW264.7 cells, $50 \mathrm{~nm}$ silica NPs with either a positive or a negative charge exhibited similar uptake levels (Kurtz-Chalot et al., 2017). In HepG2 cells, the cellular uptake of positively charged 3-aminopropyltrimethoxysilane (APTES)$\mathrm{ZnO} N \mathrm{Ns}(10-30 \mathrm{~nm})$ was greater than the uptake of pristine $\mathrm{ZnO}$ 
TABLE 2 | Cellular uptake regulated by NPs' surface chemistry.

\begin{tabular}{|c|c|c|c|c|c|}
\hline Composition & Size & $\begin{array}{l}\text { Surface chemistry/Zeta } \\
\text { potential/LogP }\end{array}$ & Cell line & Cellular uptake level & References \\
\hline Gold & $18,35,65 \mathrm{~nm}$ & $\begin{array}{l}\text { Ethanediamine, glucosamine, } \\
\text { hydroxypropylamine, taurine, linear } \\
\text { PEG }\end{array}$ & $\begin{array}{l}\text { Primary human dermal } \\
\text { microvascular endothelial } \\
\text { cells }\end{array}$ & $\begin{array}{l}\text { Ethanediamine }>\text { the rest } \\
\text { decorations }\end{array}$ & Freese et al., 2012 \\
\hline Gold & $\begin{array}{l}33 \times 30 \mathrm{~nm}, 55 \\
\times 14 \mathrm{~nm}\end{array}$ & $\begin{array}{l}\text { Poly(diallyldimethyl ammonium } \\
\text { chloride) }(50 \mathrm{mV}) \text {, CTAB ( } 40 \mathrm{mV}) \\
\text { polystyrene sulfonate }(-40 \mathrm{mV})\end{array}$ & MCF-7 & $\begin{array}{l}\text { Poly(diallyldimethyl } \\
\text { ammonium } \\
\text { chloride) }>\text { CTAB }>\text { polystyrene } \\
\text { sulfonate }\end{array}$ & Qiu et al., 2010 \\
\hline Gold & $40,80 \mathrm{~nm}$ & $\begin{array}{l}\text { Polyethyleneimine }(63.1 \mathrm{mV}) \text {, lipoic } \\
\text { acid }(-73.3 \mathrm{mV})\end{array}$ & HUVECS & $\begin{array}{l}\text { Polyethyleneimine>lipoic } \\
\text { acid }\end{array}$ & $\begin{array}{l}\text { Chandran et al., } \\
2017\end{array}$ \\
\hline Gold & $10,20,40 \mathrm{~nm}$ & $\begin{array}{l}\text { Cysteamine }(26.33 \text { to } 47.12 \mathrm{mV}) \text {, } \\
\text { citrate }(-29.28 \text { to }-38.4 \mathrm{mV}) \text {, cysteine } \\
(0.13 \text { to }-0.92 \mathrm{mV})\end{array}$ & $\begin{array}{l}\text { Monocytes and } \\
\text { macrophages }\end{array}$ & $\begin{array}{l}\text { Cysteamine }>\text { (citrate, } \\
\text { cysteine) }\end{array}$ & Oh and Park, 2014 \\
\hline Gold & $15,45 \mathrm{~nm}$ & $\begin{array}{l}\text { Poly(allyamine hydrochloride) (20.9, } \\
30.1 \mathrm{mV}), \text { PEG }(-2.1,-1.0 \mathrm{mV})\end{array}$ & $\begin{array}{l}\text { SK-BR-3 breast cancer } \\
\text { cells }\end{array}$ & $\begin{array}{l}\text { Poly(allyamine } \\
\text { hydrochloride)>PEG }\end{array}$ & Cho et al., 2010 \\
\hline Gold & $6 \mathrm{~nm}$ & $\begin{array}{l}\text { Lipoic acid and derivatives }(-40 \mathrm{mV} \\
\text { to } 60 \mathrm{mV})\end{array}$ & HeLa, HEK293, and A549 & $\begin{array}{l}\text { Positively correlated with } \\
\text { positive charge density }\end{array}$ & $\begin{array}{l}\text { Su et al., 2012; Sun } \\
\text { et al., } 2018\end{array}$ \\
\hline Gold & $6 \mathrm{~nm}$ & $\begin{array}{l}\text { Derivatives of lipoic acid (zeta } \\
\text { potential: }-5 \mathrm{mV} \text { to }-20 \mathrm{mV} \text {, LogP: } \\
-2.7 \text { to } 2.4 \text { ) }\end{array}$ & HEK293, A549, THP-1 & $\begin{array}{l}\text { Hydrophobic } \\
\text { GNP > hydrophilic GNP }\end{array}$ & $\begin{array}{l}\text { Li et al., 2015a; Sun } \\
\text { et al., } 2018\end{array}$ \\
\hline $\mathrm{TiO}_{2}$ & $50-65 \times 8 \mathrm{~nm}$ & $\mathrm{NH}_{2}(35.2 \mathrm{mV}), \mathrm{COOH}(-20.9 \mathrm{mV})$ & $\begin{array}{l}\text { Rat bone marrow } \\
\text { mesenchymal stem cells }\end{array}$ & $\mathrm{NH}_{2}>\mathrm{COOH}$ & Shrestha et al., 2016 \\
\hline $\mathrm{TiO}_{2}$ & $300 \mathrm{~nm}$ & PEG, pristine & A549, H1299 & Pristine $>$ PEG & Tedja et al., 2012 \\
\hline $\mathrm{ZnO}$ & $39 \mathrm{~nm}$ & APTES $(40 \mathrm{mV})$, pristine $(30 \mathrm{mV})$ & $\begin{array}{l}\text { THP-1 and differentiated } \\
\text { THP-1 cells }\end{array}$ & APTES=pristine & Luo et al., 2014 \\
\hline $\mathrm{ZnO}$ & $39 \mathrm{~nm}$ & $\begin{array}{l}\text { PEG }(10 \mathrm{mV} \text { ), } \\
\text { 3-aminopropyltriethoxysilane (APTES, } \\
40 \mathrm{mV} \text { ) }\end{array}$ & $\begin{array}{l}\text { THP-1, differentiated } \\
\text { THP-1 }\end{array}$ & APTES >PEG & Luo et al., 2014 \\
\hline Silica & $\begin{array}{l}20,30,50 \\
80 \mathrm{~nm}\end{array}$ & Amine, L-Ser, pristine & A549 & Amine $>$ (L-Ser, pristine) & $\begin{array}{l}\text { Ojea-Jiménez et al., } \\
2016\end{array}$ \\
\hline Silica & $50 \mathrm{~nm}$ & $\mathrm{NH}_{2}(25 \mathrm{mV}), \mathrm{COOH}(-42 \mathrm{mV})$ & RAW264.7 & $\mathrm{NH}_{2}=\mathrm{COOH}$ & $\begin{array}{l}\text { Kurtz-Chalot et al., } \\
2017\end{array}$ \\
\hline Silica & $50 \mathrm{~nm}$ & $\begin{array}{l}\mathrm{PEG}(-29 \mathrm{mV}), \mathrm{COOH}(-42 \mathrm{mV}) \\
\mathrm{NH}_{2}(25 \mathrm{mV})\end{array}$ & RAW264.7 & $\left(\mathrm{COOH}, \mathrm{NH}_{2}\right)>\mathrm{PEG}$ & $\begin{array}{l}\text { Kurtz-Chalot et al., } \\
2017\end{array}$ \\
\hline Iron oxide & $20 \mathrm{~nm}$ & PEG $(-29.74 \mathrm{mV})$ & HUVECs, macrophages & Inhibited cellular uptake & Orlando et al., 2015 \\
\hline Iron oxide & $150 \mathrm{~nm}$ & $\begin{array}{l}\text { Carboxymethyl dextran (CMX, } \\
-11.6 \mathrm{mV}), \mathrm{PEG}(-10.6 \mathrm{mV})\end{array}$ & $\begin{array}{l}\text { Microglia, astrocytes, } \\
\text { oligodendrocyte precursor } \\
\text { cells, neural stem cells }\end{array}$ & $\mathrm{CMX}>\mathrm{PEG}$ & Jenkins et al., 2016 \\
\hline SWCNTS & Length: $240 \mathrm{~nm}$ & $\mathrm{NH}_{2}(52.8 \mathrm{mV}), \mathrm{COOH}(-66.8 \mathrm{mV})$ & HeLa & $\mathrm{NH}_{2}>\mathrm{COOH}$ & $\begin{array}{l}\text { Budhathoki-Uprety } \\
\text { et al., } 2017\end{array}$ \\
\hline MWCNTS & $\begin{array}{l}\text { Diameter: } \\
\text { 10-20 } \mathrm{nm} \text {, } \\
\text { length: } 5-15 \mu \mathrm{m}\end{array}$ & $\begin{array}{l}\mathrm{COOH}(-31.93 \mathrm{mV}) \text {, pristine } \\
(-14.97 \mathrm{mV})\end{array}$ & RAW264.7 & $\mathrm{COOH}>$ pristine & Zhang T. et al., 2019 \\
\hline
\end{tabular}


TABLE 2 | Continued

\begin{tabular}{|c|c|c|c|c|c|}
\hline Composition & Size & $\begin{array}{l}\text { Surface chemistry/Zeta } \\
\text { potential/LogP }\end{array}$ & Cell line & Cellular uptake level & References \\
\hline MWCNTS & $\begin{array}{l}\text { Diameter: } \\
\text { 10-20 } \mathrm{nm}, \\
\text { length: } 5-15 \mu \mathrm{m}\end{array}$ & PEG (-15.6 mV), pristine $(-14.97 \mathrm{mV})$ & RAW264.7 & Pristine $>$ PEG & Zhang T. et al., 2019 \\
\hline Cellulose & $\begin{array}{l}10-20 \times \\
120-300 \mathrm{~nm}\end{array}$ & $\begin{array}{l}\text { Rhodamine B isothiocyanate (RBITC, } \\
8.7 \mathrm{mV}) \text {, FITC }(-46.4 \mathrm{mV})\end{array}$ & HEK293 & RBITC $>$ FITC & $\begin{array}{l}\text { Mahmoud et al., } \\
2010\end{array}$ \\
\hline Polymer & $<100 \mathrm{~nm}$ & $\begin{array}{l}\text { Poly[2-(diisopropylamino)ethyl } \\
\text { methacrylate], PEO }\end{array}$ & Telo-RF & $\begin{array}{l}\text { Poly[2- } \\
\text { (diisopropylamino)ethyl } \\
\text { methacrylate]>PEO }\end{array}$ & $\begin{array}{l}\text { De Castro et al., } \\
2018\end{array}$ \\
\hline PLGA & $170 \mathrm{~nm}$ & PEI (40 mV), BSA (-20 mV) & $\begin{array}{l}\text { Human endothelial cells } \\
\text { (CRL-1730) }\end{array}$ & $\mathrm{PEI}>\mathrm{BSA}$ & Yu et al., 2012 \\
\hline Polystyrene & $100 \mathrm{~nm}$ & $\mathrm{NH}_{2}(56 \mathrm{mV}), \mathrm{COOH}(-46 \mathrm{mV})$ & THP-1 & $\mathrm{NH}_{2}=\mathrm{COOH}$ & Lunov et al., 2011 \\
\hline QDs & $6 \mathrm{~nm}$ & $\begin{array}{l}\text { Lipoic acid }(-15 \mathrm{mV} \text { ) and derivatives } \\
\text { (zwitterionic }-5 \mathrm{mV} \text {, cationic } 20 \mathrm{mV} \text { ) }\end{array}$ & HeLa & $\begin{array}{l}\text { (Cationic, } \\
\text { anionic) }>\text { zwitterionic }\end{array}$ & Park et al., 2011 \\
\hline
\end{tabular}

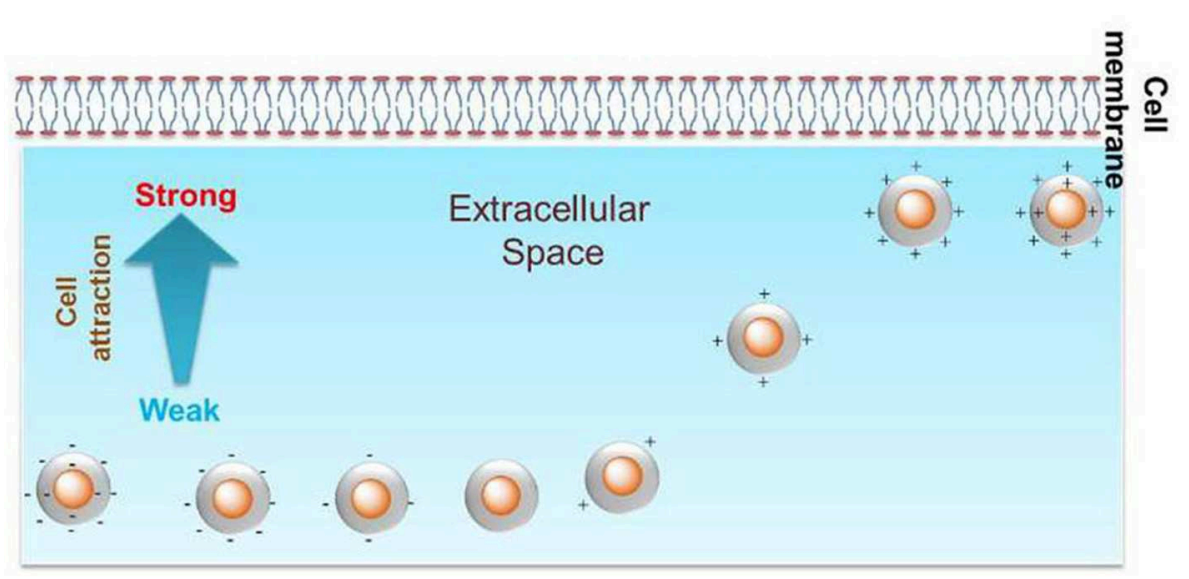

FIGURE 2 | Positive charge density could tune the cellular uptake level of GNPs in HeLa cells. Reproduced with permission from Su et al. (2012).

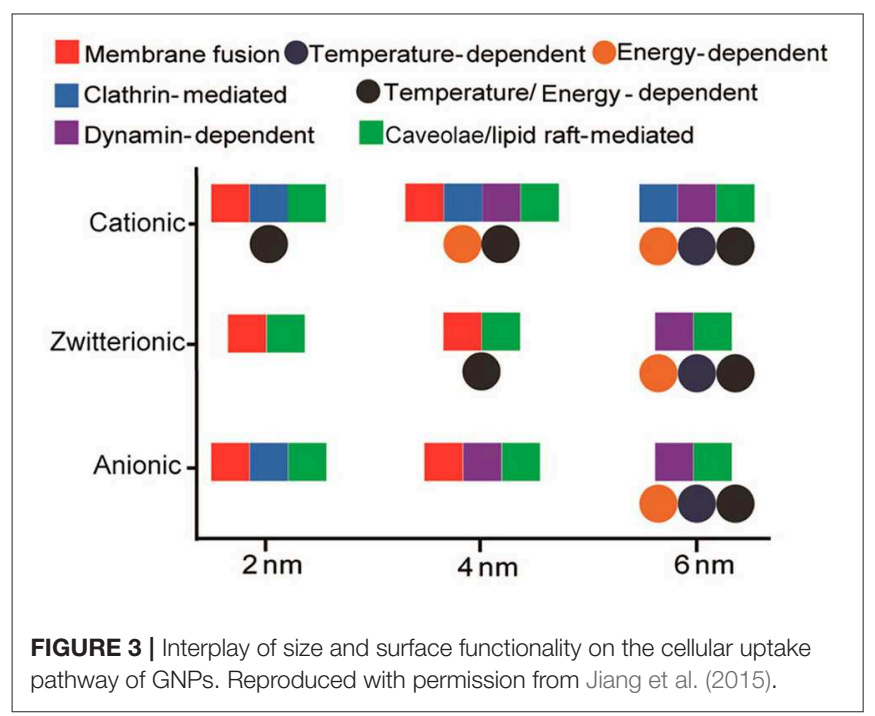

NPs (Bartczak et al., 2015). However, in THP-1 and differentiated THP-1 cells, the cellular uptake of positively charged APTES$\mathrm{ZnO}$ NPs $(39 \mathrm{~nm}$ ) was similar to that of pristine $\mathrm{ZnO}$ NPs (Luo et al., 2014).

In addition to the uptake level, the surface charge of oxide NPs can also modulate the uptake pathway. For example, an enhanced carboxyl group ratio on iron oxide NPs $(33-45 \mathrm{~nm})$ led to an increase in the negative charge density. In CaCo- 2 cells, iron oxide NPs with a lower negative charge density were prone to internalization through a macropinocytosis mechanism, while iron oxide NPs with a higher negative charge density tended to be endocytosed through clathrin- and caveolae-dependent pathways (Ayala et al., 2013).

The surface charge can tune the cellular uptake level and pathway of carbon-based NPs. Positively charged amineSWCNTs (mean length of $240 \mathrm{~nm}$ ) were internalized at a higher level than were negatively charged carboxy-SWCNTs (mean length of $177 \mathrm{~nm}$ ) in HeLa cells cultured in complete media. 

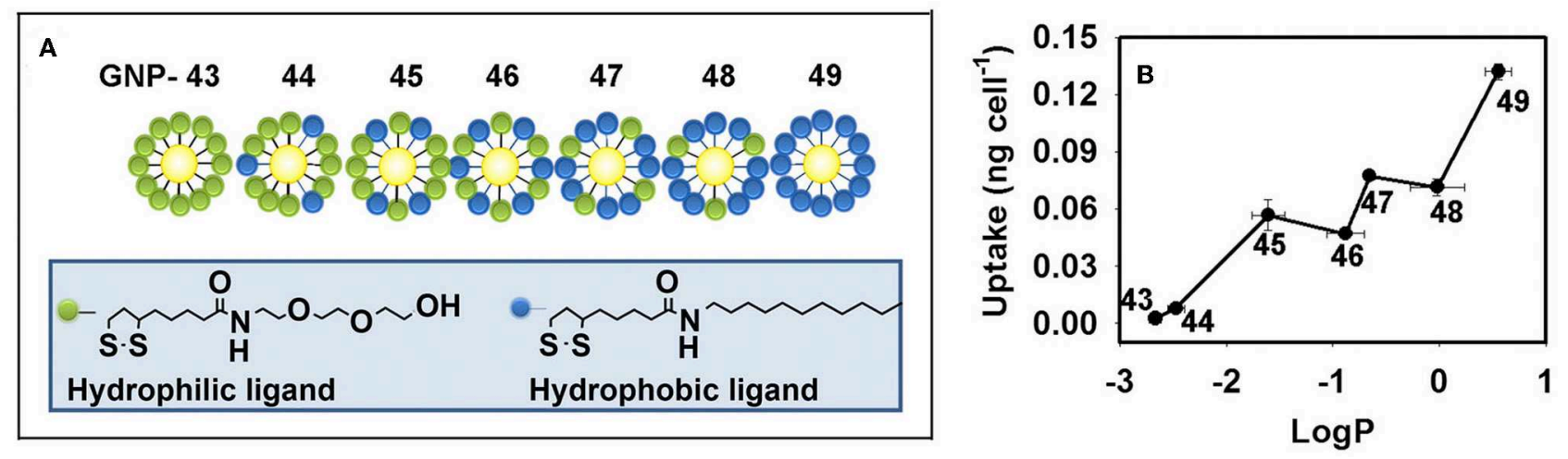

FIGURE 4 | (A) GNP library with a continuous change in hydrophobicity. (B) Hydrophobicity regulates the cellular uptake level of GNPs in macrophages. Adapted with permission from Li et al. (2015a).

The absence of serum in the medium did not affect the uptake of positively charged amine-SWCNTs; however, the absence of serum significantly enhanced the internalization of negatively charged carboxy-SWCNTs in HeLa cells (Budhathoki-Uprety et al., 2017). In RAW264.7 cells, the cellular uptake of carboxylMWCNTs (average diameter of $10-20 \mathrm{~nm}$ and length of 5$15 \mu \mathrm{m}$ ) was greater than that of pristine MWCNTs, and the BSA and IgG corona could alleviate the internalization of the carboxyMWCNTs and enhance the uptake of the pristine MWCNTs (Zhang T. et al., 2019). The internalization of carbon NPs (CNPs) smaller than $50 \mathrm{~nm}$ was systematically investigated in breast cancer cells in different stages (including the early and late metastatic stages). The internalization levels of anionic and neutral CNPs were higher than the level of cationic CNPs as the cancer progressed from the early to late metastatic stage, and the endocytosis pathway was also different for the positively/negatively/neutrally charged CNPs in different cancer stages (Srivastava et al., 2017).

For polymer NPs, the surface charge can also affect cellular uptake. Cellulose nanocrystal (CNC) is a novel material applied in regenerative medicine and drug delivery. CNCs $(10-20 \times 120-300 \mathrm{~nm})$ with a positive surface charge were significantly endocytosed by HEK293 cells, while negatively charged CNCs were not significantly internalized by these cells (Mahmoud et al., 2010). NPs decorated with zwitterionic poly[2(diisopropylamino)ethyl methacrylate] ligands were internalized at a higher level than their neutral counterparts (De Castro et al., 2018). Poly(D,L-lactide-coglycolide) (PLGA) is widely used in biomedical fields. The level to which human endothelial cells (CRL-1730) internalized PLGA NPs $(170 \mathrm{~nm})$ coated with positively charged PEI ligand was higher than the level to which they internalized BSA-PLGA NPs. The endocytosis mechanism was similar for both kinds of surface decorations, with macropinocytosis and clathrin-mediated endocytosis being the predominate mechanisms (Yu et al., 2012). The uptake level of $\mathrm{NH}_{2}$-PS NPs $(100 \mathrm{~nm})$ and COOH-PS NPs $(100 \mathrm{~nm})$ by THP1 cells were similar, while COOH-PS NPs were more likely to be endocytosed by macrophages than were $\mathrm{NH}_{2}$-PS NPs. Moreover, the internalization mechanism was different for the
$\mathrm{NH}_{2}$-PS and COOH-PS NPs taken up by macrophages compared to mechanism by which they were internalized by THP-1 cells, indicating that cell type should also be considered in determining cellular uptake (Lunov et al., 2011).

The surface charges of quantum dots (QDs) can determine the cellular uptake levels and pathways. Positively and negatively charged QDs could be massively endocytosed by HeLa cells, while QDs with zwitterionic surfaces were internalization to a lesser extent. Moreover, positively charged QDs were endocytosed by energy-dependent and energy-independent pathways, while negatively charged QDs were only endocytosed by energydependent pathways (Park et al., 2011). Cationic CdSe/ZnS QDs (4-5 nm) induced clathrin-mediated endocytosis in HeLa cells, while zwitterionic-lipophilic QDs mainly interacted with lipid rafts in the cell membrane, which led to lipid raftmediated endocytosis (Chakraborty and Jana, 2015). In another study, COOH-PEG-QDs were found to be internalized through lipid raft- and SRA-mediated mechanisms in A549 cells, which were associated with the activated NF- $\mathrm{KB}$ pathway, while $\mathrm{NH}_{2}-$ PEG-QDs were mainly internalized through lipid raft-mediated endocytosis and activated p38 MAPK/AP-1 signaling cascades (Zhang et al., 2013).

\section{Hydrophobicity}

The hydrophobicity of GNPs can tune the cellular uptake level. By varying the ratio of hydrophobic ligands to hydrophilic ligands on the NP surface, a GNP library $(6 \mathrm{~nm})$ with continuously changing hydrophobicity was synthesized. In HEK293, A549, and THP-1 cells, the cellular uptake levels were found to be positively correlated with the hydrophobicity of the GNPs (Figure 4) (Li et al., 2015a; Sun et al., 2018).

To improve the bioavailability of NPs, PEG has been frequently used to modify the NP surfaces. PEG decorations could enhance NP hydrophilicity, dispersibility, and inhibit opsonization, thus significantly reducing the internalization of various types of NPs. For example, PEG reduced the uptake level of iron oxide NPs $(\sim 20 \mathrm{~nm})$ in HUVECs and macrophages, and this PEG decoration-reduced uptake was more noticeable in macrophages than it was in HUVECs (Orlando et al., 2015). In 
another study, PEG decoration on iron oxide NPs alleviated the internalization in multiple (immune and non-immune) brain cell types, including microglia, astrocytes, oligodendrocyte precursor cells, and neural stem cells (Jenkins et al., 2016). PEG decoration on positively and negatively charged silica NPs $(50 \mathrm{~nm})$ reduced the level of NP internalization into RAW264.7 cells (KurtzChalot et al., 2017). Few $\mathrm{TiO}_{2}$ NPs decorated with PEG-like polymers were internalized into A549 and H1299 cells (Tedja et al., 2012). In another study, PEG decorated $\mathrm{TiO}_{2}$ NRs (50$65 \mathrm{~nm}$ in length and $8 \mathrm{~nm}$ in width) were internalized to a lesser extent into rat bone marrow mesenchymal stem cells compared to the internalized levels of $\mathrm{NRs}$ with $\mathrm{NH}_{2}$ or $\mathrm{COOH}$ decorations (Shrestha et al., 2016). PEG decoration on ZnO NPs (39 nm) reduced the internalization into THP-1 and differentiated THP1 cells compared to levels of NPs with APTES decoration that were internalized (Luo et al., 2014). Regarding MWCNTs (average diameter of $10-20 \mathrm{~nm}$ and length of 5-15 $\mu \mathrm{m}$ ), PEG decoration reduced the number taken up by RAW264.7 cells (Zhang T. et al., 2019).

\section{Combinatorial Surface Modifications}

The impact of surface chemistry on cellular uptake was investigated based on a combinatorial MWCNT library. Gao et al. found that modification of $\mathrm{COOH}-\mathrm{MWCNTs}$ could redirect them from binding to mannose receptors to binding to scavenger receptors (Gao et al., 2011). In addition, the impact of surface chemistry on folate targeting was investigated by Zhou et al., who used a dual-ligand GNP array to assess Hela, KB, and HepG2 cells. The secondary ligand on GNPs may interact with the receptors surrounding the folate receptors according to their different intensities, resulting in a specific, unique level of cellular uptake (Zhou et al., 2011).

\section{OXIDATIVE STRESS}

Reactive oxygen species (ROS), including $\mathrm{O}_{2}^{-}, \mathrm{OH}^{-}$, and $\mathrm{H}_{2} \mathrm{O}_{2}$, are the derivatives of oxygen in physiological environments. ROS are generated mainly from mitochondria and NADPH oxidase in cells. The electron leakage in the mitochondrial respiratory chain is captured by oxygen, which leads to ROS generation (Murphy, 2009). NADPH oxidase is found in both phagocytic and non-phagocytic cells. Parts of the subunits are located on the cell membrane, and the other parts are located in the cytoplasm under quiescent conditions. Once activated, subunits in the cytoplasm will translocate to the cell membrane, resulting in the assembly of all the subunits (Bedard and Krause, 2007). The overproduction of ROS leads to oxidative stress, which is considered to be a main mechanism of nanotoxicity in recent years (Nel et al., 2006).

Intracellular ROS and oxidative stress could be determined by various methods. For example, fluorescent probes, including dichlorodihydrofluorescein and its derivatives, dihydroethidium, MitoSOX ${ }^{\mathrm{TM}}$ Red, etc., are the most convenient and widely used methods (Xia et al., 2006; Karlsson et al., 2008; Passagne et al., 2012). According to the hierarchical oxidative stress model, ROS stimulate the production of antioxidases. Therefore, the expression of an antioxidase, such as heme oxygenase-1, could be used to detect oxidative stress (Nel et al., 2006; Yu et al., 2012). Moreover, intracellular ROS induce a decrease in the GSH level and GSH/GSSG ratio, which are also used as oxidative stress markers (Piao et al., 2011; Nguyen et al., 2013). In this section, we summarize recently published literatures related to the regulation of oxidative stress by NPs' surface chemistry (Table 3 ).

\section{Surface Charge}

To investigate the impact of surface charge on cellular oxidative stress, we constructed two libraries of GNPs $(6 \mathrm{~nm})$ that exhibit continuously changing in positive and negative charges. After exposing GNPs to A549 and HEK293 cells, we found that positive charge density was positively correlated with ROS level, while negative charge density exhibited no impact on intracellular ROS level. Studies on ROS-related mechanisms indicated that the cellular uptake of positively charged GNPs induced cell membrane depolarization and calcium channel opening and ultimately stimulated mitochondria to generate intracellular oxidative stress (Figure 5A) (Sun et al., 2018). In another study, it was also found that positively charged PEI-GNRs $(55.7 \times$ $13.2 \mathrm{~nm}$ ) led to a decrease in intracellular GSH levels and GSH/GSSG ratios in A549 cells, while negatively charged PSSGNRs exhibited no influence on GSH levels (Liu et al., 2016).

The surface charge of oxide NPs could also regulate the cellular oxidative stress level. For example, positively charged $\mathrm{ZnO}$ NPs $(29 \mathrm{~nm})$ induced the highest ROS level in WIL2NS human lymphoblastoid cells, followed by negatively charged oleic acid and poly(methacrylic acid) decorated ZnO NPs (Yin et al., 2010). In A549 cells and human skin fibroblasts (HSFs), it was also determined that positively charged ZnO NPs $(98 \mathrm{~nm})$ were more prone to inducing ROS and mitochondria membrane depolarization than were their negatively charged counterparts (Keleştemur et al., 2017). Iron oxide NPs decorated with neutrally charged glucose ligands elicited higher ROS levels in CT26 colorectal cancer cells than did their citrate-decorated counterparts with a negative surface charge (Wydra et al., 2015). In rat bone marrow mesenchymal stem cells, pristine and $\mathrm{NH}_{2}$ $\mathrm{TiO}_{2}$ NRs $(60 \times 8 \mathrm{~nm})$ induced ROS production, while COOH$\mathrm{TiO}_{2}$ NRs had no significant impact (Shrestha et al., 2016). Therefore, it seems that the positively charged and neutral oxide NPs described above are more likely to induce ROS than are their negatively charged counterparts. However, in another study, it was found that negatively charged silica NPs induced ROS in RAW264.7 cells, while positively charged silica NPs had no influence on ROS production (Liu T.-P. et al., 2015).

COOH-MWCNTs induced higher ROS levels than neutrally charged MWCNTs induced in macrophages (Gao et al., 2011). However, in HUVECs, both pristine and COOH-MWCNTs elicited similar levels of ROS and decreased GSH levels (Long et al., 2018). As to graphene, GO and $\mathrm{COOH}$-graphene induced similar amounts of ROS in HepG2 cells (Lammel et al., 2013). In macrophages, a positively charged PEI decoration on graphene led to the highest level of ROS, followed by a neutral decoration (Luo et al., 2015). As to nanodiamonds, the impact of surface charge on intracellular ROS level was also investigated. For example, decoration of negatively charged ligands on 
TABLE 3 | Oxidative stress regulated by NPs' surface chemistry.

\begin{tabular}{|c|c|c|c|c|c|}
\hline Composition & Size & $\begin{array}{l}\text { Surface chemistry/Zeta } \\
\text { potential/LogP }\end{array}$ & Cell line & Oxidative stress level & References \\
\hline Gold & $6 \mathrm{~nm}$ & $\begin{array}{l}\text { Lipoic acid and derivatives (- } 40 \mathrm{mV} \\
\text { to } 60 \mathrm{mV} \text { ) }\end{array}$ & HEK293, A549 & $\begin{array}{l}\text { Positively correlated with } \\
\text { positive charge density }\end{array}$ & Sun et al., 2018 \\
\hline Gold & $55.7 \times 13.2 \mathrm{~nm}$ & $\begin{array}{l}\text { PEI, poly sodium-p-styrene sulfonate } \\
\text { (PSS) }\end{array}$ & A549 & $\mathrm{PEI}>\mathrm{PSS}$ & Liu et al., 2016 \\
\hline Gold & $6 \mathrm{~nm}$ & $\begin{array}{l}\text { Derivatives of lipoic acid (zeta } \\
\text { potential: }-5 \mathrm{mV} \text { to }-20 \mathrm{mV} \text {, LogP: } \\
-2.7 \text { to } 2.4 \text { ) }\end{array}$ & HEK293, A549 & $\begin{array}{l}\text { Hydrophobic } \\
\text { GNP> hydrophilic GNP }\end{array}$ & Sun et al., 2018 \\
\hline Gold & $2 \mathrm{~nm}$ & Hydrophobic alkyl ends & HeLa & $\begin{array}{l}\text { Positively correlated with } \\
\text { the length of alkyl }\end{array}$ & $\begin{array}{l}\text { Chompoosor et al., } \\
2010\end{array}$ \\
\hline $\mathrm{ZnO}$ & $29 \mathrm{~nm}$ & $\begin{array}{l}\text { Pristine (4.49 mV), oleic acid } \\
\text { (10.15 mV), poly(methacrylic acid) } \\
(-40.21 \mathrm{mV})\end{array}$ & $\begin{array}{l}\text { WIL2-NS human } 364 \\
\text { lymphoblastoid cells }\end{array}$ & $\begin{array}{l}\text { Pristine }>\text { [oleic acid, } \\
\text { poly(methacrylic acid)] }\end{array}$ & Yin et al., 2010 \\
\hline $\mathrm{ZnO}$ & $98 \mathrm{~nm}$ & $\begin{array}{l}\text { 3-Aminopropyl triethoxysilane } \\
\text { (APTES, } 11.1 \mathrm{mV}) \text {, pristine }(-30.4 \mathrm{mV})\end{array}$ & $\begin{array}{l}\text { A549, human skin } \\
\text { fibroblasts (HSFs) }\end{array}$ & APTES $>$ pristine & $\begin{array}{l}\text { Keleştemur et al., } \\
2017\end{array}$ \\
\hline Iron oxide & $70 \mathrm{~nm}$ & Glucose, citric acid & $\begin{array}{l}\text { CT26 colorectal cancer } \\
\text { cells }\end{array}$ & Glucose > citric acid & Wydra et al., 2015 \\
\hline $\mathrm{TiO}_{2}$ & $60 \times 80 \mathrm{~nm}$ & $\begin{array}{l}\text { Pristine }(21.4 \mathrm{mV}), \mathrm{NH}_{2}(35.2 \mathrm{mV}) \text {, } \\
\mathrm{COOH}(-20.9 \mathrm{mV})\end{array}$ & $\begin{array}{l}\text { Rat bone marrow } \\
\text { mesenchymal stem cells }\end{array}$ & (Pristine, $\mathrm{NH}_{2}$ ) $>\mathrm{COOH}$ & Shrestha et al., 2016 \\
\hline Silica & $45 \mathrm{~nm}$ & $\begin{array}{l}\text { 3-trihydroxysilyl)propylmethyl- } \\
\text { phosphonate (THPMP, }-52 \mathrm{mV} \text { ), } \\
\mathrm{N} \text {-Trimethoxysilylpropyl-N,N,N- } \\
\text { trimethylammonium chloride (TMAC, } \\
38.9 \mathrm{mV} \text { ) }\end{array}$ & RAW264.7 & THPMP > TMAC & Liu T.-P. et al., 2015 \\
\hline Silica & $50 \mathrm{~nm}$ & $\begin{array}{l}\text { Hydrophobic linker/ hydrophilic linker } \\
(-1.53 \mathrm{mV} \text { to }-13.6 \mathrm{mV})\end{array}$ & RAW264.7 & $\begin{array}{l}\text { Hydrophobic } \\
\text { linker }>\text { hydrophilic linker }\end{array}$ & Chen et al., 2017 \\
\hline MWCNTS & N.A. & $\mathrm{COOH}$, neutral ligand & Macrophage & $\mathrm{COOH}>$ neutral ligand & Gao et al., 2011 \\
\hline MWCNTS & $\begin{array}{l}\text { Diameter: } \\
\text { 20-30 nm }\end{array}$ & $\mathrm{COOH}$, pristine & HUVECs & $\mathrm{COOH}=$ pristine & Long et al., 2018 \\
\hline Graphene & $<50 \mathrm{~nm}$ & $\begin{array}{l}\text { Graphene oxide }(-8.3 \mathrm{mV}) \text {, carboxyl } \\
\text { grapheme }(-55.1 \mathrm{mV})\end{array}$ & HepG2 & $\begin{array}{l}\text { Graphene oxide=carboxyl } \\
\text { grapheme }\end{array}$ & Lammel et al., 2013 \\
\hline Graphene & $200 \mathrm{~nm}$ & PEI (40.4 mV), pristine $(-7.36 \mathrm{mV})$ & macrophage & PEl>pristine & Luo et al., 2015 \\
\hline Nanodiamonds & $5 \mathrm{~nm}$ & $\mathrm{OH}(-12.2 \mathrm{mV})$, pristine $(1 \mathrm{mV})$ & A549 & $\mathrm{OH}=$ pristine & $\begin{array}{l}\text { Solarska-Sciuk } \\
\text { et al., } 2014\end{array}$ \\
\hline Nanodiamonds & $6-7 \mathrm{~nm}$ & $\mathrm{NH}_{3}+(0.3 \mathrm{mV}), \mathrm{COOH}(-37.3 \mathrm{mV})$ & $\begin{array}{l}\text { Rat bone mesenchymal } \\
\text { stem cells }\end{array}$ & $\mathrm{NH}_{3}+>\mathrm{COOH}$ & Zhang Y. et al., 2019 \\
\hline Nanodiamonds & $50-60 \mathrm{~nm}$ & $\begin{array}{l}\mathrm{COOH}(-25 \mathrm{mV}), \mathrm{PVP}(-15 \mathrm{mV}), \mathrm{OH} \\
(-10 \mathrm{mV}) \text {, imidazolium (IM, } 10 \mathrm{mV}) \\
\text { tertiary methyl ammonium ethyl } \\
\text { methacrylate cation (TMAEA, } 20 \mathrm{mV})\end{array}$ & HeLa & $\begin{array}{l}\mathrm{IM}>\mathrm{TMAEA}>\mathrm{COOH}, \mathrm{PVP} \\
\mathrm{OH})\end{array}$ & $\begin{array}{l}\text { Vankayala et al., } \\
2014\end{array}$ \\
\hline Polystyrene & $50 \mathrm{~nm}$ & $\begin{array}{l}\mathrm{NH}_{2}(43 \mathrm{mV}), \mathrm{COOH}(-46.7 \mathrm{mV}) \\
\text { pristine }(-50.5 \mathrm{mV})\end{array}$ & $\begin{array}{l}\text { Human alveolar epithelial } \\
\text { type I-like cells (TT1), } \\
\text { primary human alveolar } \\
\text { macrophages, primary } \\
\text { human alveolar type } 2 \\
\text { (AT2) cells }\end{array}$ & $\begin{array}{l}\mathrm{NH}_{2}>(\mathrm{COOH} \text {, pristine }) \text { for } \\
\text { the first two cell lines. } \\
\mathrm{NH}_{2}=\mathrm{COOH}=\text { pristine for } \\
\text { the last cell line }\end{array}$ & $\begin{array}{l}\text { Ruenraroengsak } \\
\text { and Tetley, } 2015\end{array}$ \\
\hline Polystyrene & $60 \mathrm{~nm}$ & $\mathrm{NH}_{2}(40.3 \mathrm{mV}), \mathrm{COOH}(-27.6 \mathrm{mV})$ & RAW264.7 & $\mathrm{NH}_{2}>\mathrm{COOH}$ & Xia et al., 2006 \\
\hline
\end{tabular}

N.A., not available.

nanodiamonds $(10 \mathrm{~nm})$ could not enhance the ROS level in A549 cells (Solarska-Sciuk et al., 2014). However, in another paper, it was found that both positively and negatively charged nanodiamonds $(6-7 \mathrm{~nm})$ could elicit ROS production in rat bone mesenchymal stem cells, and the former induced higher ROS level than the latter (Zhang Y. et al., 2019). Moreover, Vankayala et al. also found that positively charged nanodiamonds (50$60 \mathrm{~nm}$ ) induced higher ROS level than negatively charged, zwitterionic, and neutral nanodiamonds in HeLa cells (Vankayala et al., 2014).

Unmodified PS NPs and PS NPs with amine and carboxyl groups $(50 \mathrm{~nm})$ could regulate ROS levels in different cell lines. In human alveolar epithelial type I-like cells (TT1) and primary human alveolar macrophages, amine-PS NPs induced the highest ROS level, followed by unmodified and carboxyl-PS NPs. In primary human alveolar type 2 (AT2) cells, however, these three 

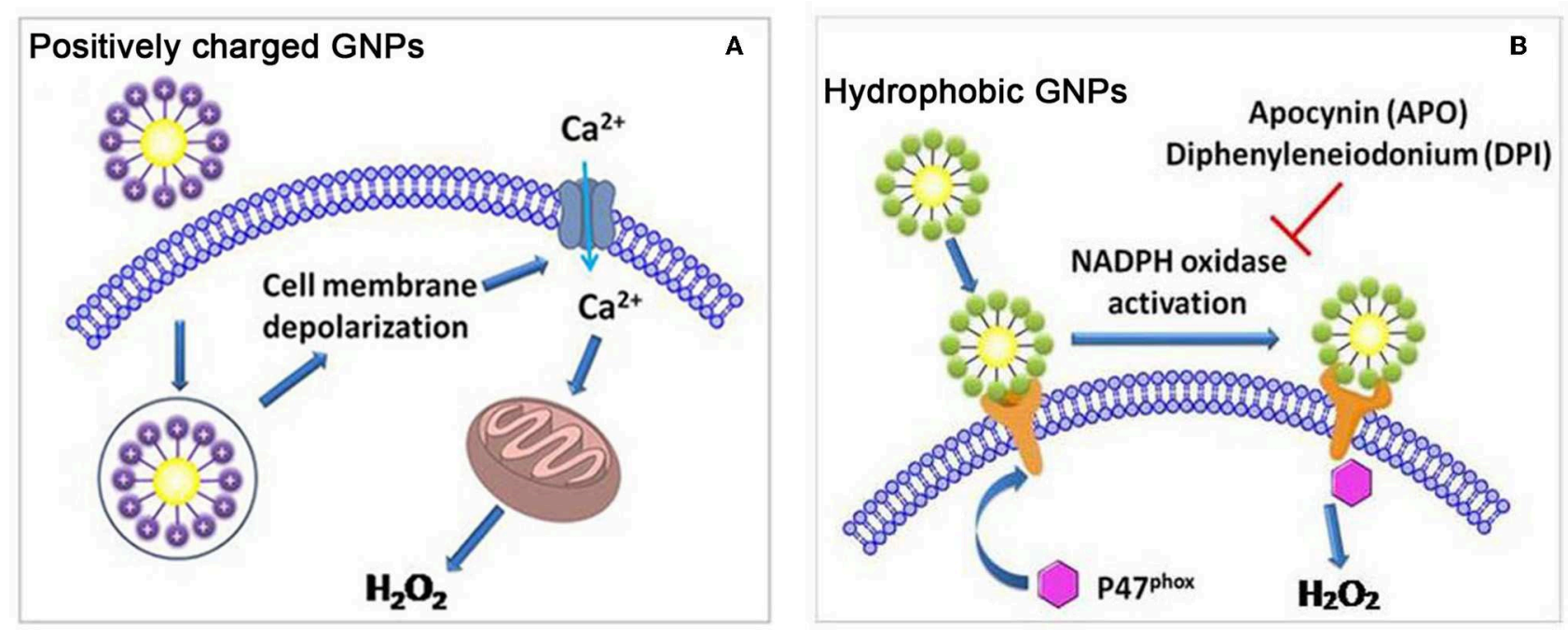

FIGURE 5 | (A) Positively charged GNPs induce cell membrane depolarization and calcium channel opening, and stimulate mitochondria to generate intracellular oxidative stress. (B) Hydrophobic GNPs induce oxidative stress by perturbing NADPH oxidase. Adapted with permission from Sun et al. (2018).

kinds of decorations elicited similar levels of intracellular ROS (Ruenraroengsak and Tetley, 2015). In another study, it was found that amine-PS NPs $(60 \mathrm{~nm})$ elicited mitochondrial ROS production, while carboxyl-PS NPs with the same size had no impact on intracellular ROS levels (Xia et al., 2006).

\section{Hydrophobicity}

By varying the ratio of hydrophobic/hydrophilic ligands on the GNP surface, we synthesized a GNP library in which the NPs had continuously changing hydrophobicity. In A549 and HEK293 cells, GNP hydrophobicity was positively correlated with ROS level. Moreover, hydrophobic GNPs were found to elicit the translocation of $\mathrm{P} 47^{\mathrm{phox}}$ subunits to the cell membrane, leading to NADPH oxidase-dependent oxidative stress (Figure 5B) (Sun et al., 2018). In other studies, hydrophobic decorations on NPs were also more likely to elicit ROS production. For example, the length of hydrophobic alkyl ends on positively charged ligands was positively correlated with the ROS level induced by the GNPs ( $2 \mathrm{~nm}$ ) in HeLa cells (Chompoosor et al., 2010). A hydrophobic linker decorated on silica NPs $(50 \mathrm{~nm})$ induced higher ROS production than did a hydrophilic linker decoration (Chen et al., 2017).

\section{AUTOPHAGY}

Autophagy is a self-eating process that leads to the degradation of dysfunctional cellular components. Autophagy can be divided into three categories: macroautophagy, microautophagy, and chaperone-mediated autophagy (Levine and Kroemer, 2008; Mizushima et al., 2008). Various approaches can be used to determine autophagy the cell undergoes. For example, TEM can reveal the morphology of autophagic structures (Yu et al., 2014). The conversion of LC3-I to LC3-II is a biomarker of autophagy and is usually determined by Western blotting. Moreover, green fluorescent protein (GFP)-LC3 transfected cell lines can be used for high-throughput screening of autophagy (Wu et al., 2014). A high level of autophagy induced by NPs may lead to autophagy-related cell death or cytotoxicity (Chen et al., 2005; Liu et al., 2011). In this section, we summarize recently published literatures related to the regulation of autophagy by NPs' surface charge, hydrophobicity, and combinatorial surface modifications (Table 4).

\section{Surface Charge}

Positively charged CTAB-GNRs could induce ROS and the transformation of LC3-I to LC3-II in HCT116 cells. However, negatively charged PSS decoration did not significantly induce autophagy (Wan et al., 2015). In another study, it was also found that CTAB-GNRs $(55 \times 14 \mathrm{~nm})$ could induce autophagy, as evidenced by LC3-II conversion and p62 degradation, in A549 and MRC-5 cells. Moreover, the autophagy pathway stimulated by CTAB-GNRs is AKT-mTOR dependent. However, PSS and PDDAC decorations negligibly induced autophagy (Figure 6) (Li et al., 2015b). In addition to GNRs, the surface charge of carbon-based NPs can also tune autophagy levels and stimulate the related pathways. In A549 cells, $\mathrm{NH}_{2}$-graphene quantum dots (GQDs) induced cellular autophagy as evidenced by LC3 fluorescence tracking, LC3-II conversion, and autophagosome accumulation, while COOH-GQDs had no impact of autophagy (Xie Y. et al., 2019). In another study, the autophagy level induced by GO-decorated NPs with neutrally charged ligands was slightly higher than that of the negatively charged decorated NPs in RAW264.7 cells (Park et al., 2015). Therefore, it seems that positively and neutrally charged NPs are more likely to induce autophagy than are negatively charged NPs.

\section{Hydrophobicity}

Hexane decoration on positively charged GNPs $(10 \mathrm{~nm})$ could elicit autophagy in HUVECs, and the number of hydrophobic hexanes in the ligand was positively correlated with the 
TABLE 4 | Autophagy regulated by NPs' surface chemistry.

\begin{tabular}{|c|c|c|c|c|c|}
\hline Composition & Size & $\begin{array}{l}\text { Surface chemistry/Zeta } \\
\text { potential/LogP }\end{array}$ & Cell line & Autophagy level & References \\
\hline Gold & N.A. & $\begin{array}{l}\text { CTAB }(40 \mathrm{mV}) \text {, polystyrene sulfonate } \\
\text { (PSS, }-60 \mathrm{mV})\end{array}$ & HCT116 & CTAB $>$ PSS & Wan et al., 2015 \\
\hline Gold & $55 \times 14 \mathrm{~nm}$ & $\begin{array}{l}\text { CTAB, PSS, poly } \\
\text { (diallyldimethylammonium chloride) } \\
\text { (PDDAC) }\end{array}$ & A549, MRC-5 & CTAB > (PSS, PDDAC) & Li et al., 2015b \\
\hline Gold & $10 \mathrm{~nm}$ & Hexane & HUVECS & Enhanced autophagy level & $\begin{array}{l}\text { Manshian et al., } \\
2014\end{array}$ \\
\hline $\mathrm{ZnO}$ & $100,130 \mathrm{~nm}$ & $\begin{array}{l}\text { Triethoxycaprylylsilane (hydrophobic, } \\
-16.67 \mathrm{mV}), \text { pristine }(-19.53 \mathrm{mV})\end{array}$ & $\begin{array}{l}\text { A549-macrophage } \\
\text { co-culture }\end{array}$ & Triethoxycaprylylsilane < pristine & Liu et al., 2019 \\
\hline Graphene & $3.5-5 \mathrm{~nm}$ & $\mathrm{NH}_{2}, \mathrm{COOH}$ & A549 & $\mathrm{NH}_{2}>\mathrm{COOH}$ & Xie Y. et al., 2019 \\
\hline Graphene & N.A. & Dodecylamine, sodiumdodecyl sulfate & RAW264.7 & $\begin{array}{l}\text { Dodecylamine > sodiumdodecyl } \\
\text { sulfate }\end{array}$ & Park et al., 2015 \\
\hline SWCNTS & N.A. & $\mathrm{COOH}, \mathrm{PEG}$ & A549 & $\mathrm{COOH}>\mathrm{PEG}$ & Liu et al., 2011 \\
\hline
\end{tabular}

N.A., not available.

autophagy level (Manshian et al., 2014). However, hydrophobic $\mathrm{ZnO}$ NPs $(130 \mathrm{~nm})$ elicited lower expression of ATG7 gene than pristine ZnO NPs (100 nm) in A549-macrophage co-culture (Liu et al., 2019). COOH decorated SWCNTs induce autophagyrelated cell death in A549 cells, while PEG decoration on SWCNTs could significantly reduce the autophagy level (Liu et al., 2011).

\section{Combinatorial Surface Modifications}

We found that the surface modification on MWCNTs could tune autophagy in U87 and HEK293 cells. A total of 84 kinds of surface modification on MWCNTs could tune cell autophagy to various levels. Moreover, MWCNTs with diverse decorations could bind to different cell surface receptors and subsequently induced autophagy by activating diverse intracellular signaling pathways, including mTOR-dependent or -independent pathways ( $\mathrm{Wu}$ et al., 2014).

\section{INFLAMMATION}

NP-induced bioeffects, including the induction of intracellular oxidative stress and the activation of receptors on cell membranes, may subsequently lead to the activation of the MAPK and NF- $\mathrm{B}$ pathways, which results in the release of inflammation-related cytokines. A high level of inflammation could elicit cytotoxicity (Xia et al., 2006; Gao et al., 2011). In this section, we summarize recently published literatures related to the regulation of inflammation by NPs' surface charge, hydrophobicity, and combinatorial surface modifications (Table 5).

\section{Surface Charge}

GNRs $(50 \times 15 \mathrm{~nm})$ decorated with PEG-NH 2 , PEG-OH, or PEG-COOH were exposed to primary human blood phagocytes, and the release of proinflammatory cytokines was measured. PEG-COOH and PEG-OH could enhance the production of IL$1 \beta$ and CCL2, while PEG-NH$H_{2}$ did not affect the production of IL-1 $\beta$ or CCL2. PEG-COOH could enhance the production of IL-6, and the remaining decorations exerted no influence on IL-6 production (Bartneck et al., 2010). In RAW264.7 macrophages, negatively charged silica NPs $(50 \mathrm{~nm})$ induced the highest secretion of proinflammatory TNF- $\alpha$, followed by neutral and positively charged silica NPs (Kurtz-Chalot et al., 2017). Therefore, for these NPs, negatively charged decorations are more prone to elicit the release of proinflammatory cytokines than are positively charged decorations.

Surface decoration on QDs $(8-10 \mathrm{~nm})$, namely, negatively charged $\mathrm{COOH}-\mathrm{PEG}$ or $\mathrm{COOH}$, positively charged $\mathrm{NH}_{2}-\mathrm{PEG}$, and neutrally charged $\mathrm{HO}-\mathrm{PEG}$ and $\mathrm{CH}_{3} \mathrm{O}-\mathrm{PEG}$, could regulate the mRNA levels of IL-1 $\beta$, TNF- $\alpha$, and CCL5 in A549- and THP1-derived macrophages. In A549 cells, COOH-PEG and $\mathrm{COOH}$ decorations enhanced the mRNA levels of IL-1 $\beta$ and CCL5, and $\mathrm{COOH}-\mathrm{PEG}, \mathrm{NH}_{2}-\mathrm{PEG}$, and $\mathrm{COOH}$ decorations enhanced the mRNA levels of TNF- $\alpha$. In macrophages, COOH-PEG, $\mathrm{NH}_{2}$ PEG, HO-PEG, and $\mathrm{COOH}$ decorations enhanced the expression of IL-1 $\beta$; COOH-PEG and $\mathrm{COOH}$ decorations enhanced the expression of TNF- $\alpha$; and COOH-PEG enhanced the expression of CCL5 (Zhang et al., 2013).

A neutral decoration on MWCNTs is more likely to elicit the secretion of proinflammatory cytokines than is a negatively charged decoration. For example, in HUVECs, pristine MWCNTs did not affect the secretion of TNF- $\alpha$, while COOHMWCNTs slightly inhibited the release of TNF- $\alpha$ (Long et al., 2018). In another study, pristine MWCNTs elicited higher levels of IL- $1 \beta$ and IL- 18 secretion in the $\mathrm{C} 57 \mathrm{Bl} / 6$ alveolar macrophage model than did COOH-MWCNTs (Hamilton et al., 2013).

The protein corona could also affect the secretion of proinflammatory cytokines. For example, without BSA or IgG coronas, COOH-MWCNTs induced higher levels of IL-1 $\beta$ and TNF- $\alpha$ release than the pristine MWCNTs in RAW264.7 cells. With BSA coronas, pristine MWCNTs induced higher levels of IL-1 $\beta$ than did COOH-MWCNTs, and both kinds of MWCNTs induced similar levels of TNF- $\alpha$. With IgG coronas, pristine MWCNTs induced higher levels of TNF- $\alpha$ than did COOHMWCNTs, and both kinds of MWCNTs induced similar levels of IL-1 $\beta$ (Zhang T. et al., 2019). 


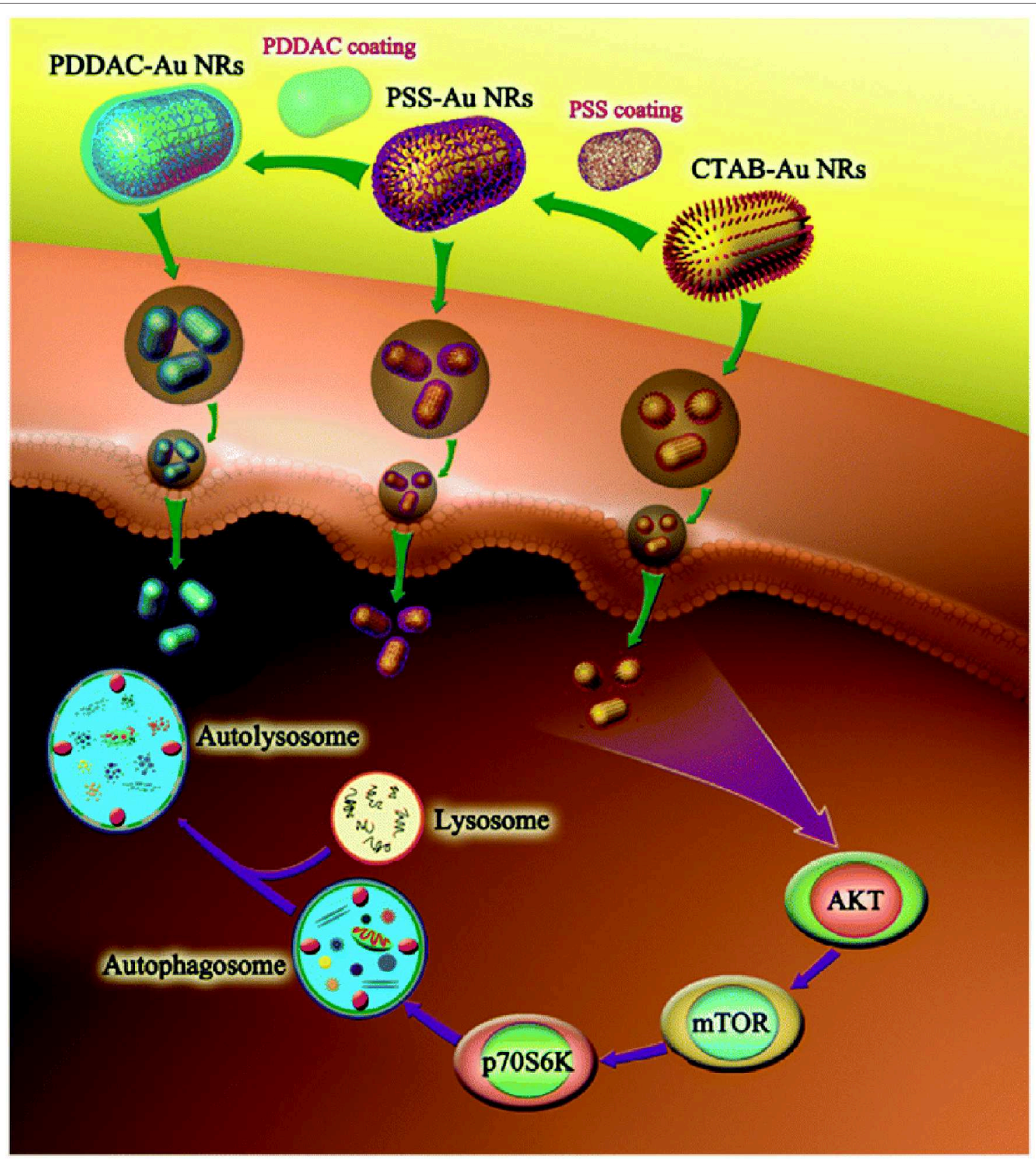

FIGURE 6 | CTAB-GNRs induce autophagy through mTOR-dependent pathway while PSS- and PDDAC-GNRs do not cause an obvious autophagy process. Reproduced with permission from Li et al. (2015b).

Except for these in vitro investigations mentioned above, a series of in vivo experiments were also conducted to investigate the impact of surface charge on inflammation. For example, positively charged GNPs $(10.4 \pm 2.5 \mathrm{~nm})$ administrated in mice led to inflammatory lesions (Bogdanov et al., 2015). Rats treated with positively charged graphene nanoplatelets ( $<5 \mathrm{~nm}$ thick, $<2 \mu \mathrm{m}$ in diameter) induced greater pulmonary inflammation than negatively charged counterparts (Lee et al., 2017). Mice treated with cationic liposomes (100-150 nm) triggered pulmonary inflammation, while neutral and anionic liposomes exhibited normal pulmonary histology (Wei et al., 2015). Cationic nanostructured lipid carriers (NLCs, <200 nm) led to the diffusion of inflammatory cells in the underlying lamina propria, however, rats treated with anionic NLCs exhibited normal structure of the lining epithelium (Gabal et al., 2014). $\mathrm{TiO}_{2}$ nanowires (diameter: $200-400 \mathrm{~nm}$ ) with different negative charges could regulate inflammation in vivo. $\mathrm{TiO}_{2}$ nanowires with lowest negative charge induced the highest level of cytokines in the BAL fluid of mice (Park et al., 2013). 
TABLE 5 | Inflammation regulated by NPs' surface chemistry.

\begin{tabular}{|c|c|c|c|c|c|}
\hline Composition & Size & $\begin{array}{l}\text { Surface chemistry/Zeta } \\
\text { potential/LogP }\end{array}$ & Cell line/Animal model & Inflammation level & References \\
\hline Gold & $50 \times 15 \mathrm{~nm}$ & $\begin{array}{l}\text { PEG-NH }{ }_{2}, \text { PEG-OH }(-4.5 \mathrm{mV}) \\
\text { PEG-COOH }(-23.2 \mathrm{mV})\end{array}$ & $\begin{array}{l}\text { Primary human blood } \\
\text { phagocytes }\end{array}$ & $\begin{array}{l}(\mathrm{PEG}-\mathrm{OH}, \\
\text { PEG-COOH)>PEG-NH} 2\end{array}$ & Bartneck et al., 2010 \\
\hline Gold & $10.4 \mathrm{~nm}$ & $\begin{array}{l}\text { Methoxypoly-ethylene glycol-graf } \\
\text { t-poly(L-lysine) copolymer } \\
\text { (MPEG-gPLL, 3.7 mV) }\end{array}$ & Mice & $\begin{array}{l}\text { Induced inflammatory } \\
\text { lesions }\end{array}$ & $\begin{array}{l}\text { Bogdanov et al., } \\
2015\end{array}$ \\
\hline Gold & $2 \mathrm{~nm}$ & $\begin{array}{l}\text { Hyamine (LogP of end group: } \\
0.63-5.35)\end{array}$ & Splenocytes & $\begin{array}{l}\text { Positively correlated with } \\
\text { hydrophobicity }\end{array}$ & Moyano et al., 2012 \\
\hline Gold & $35 \times 10 \mathrm{~nm}$ & $\begin{array}{l}\text { Mercaptohexadecanoic acid } \\
(-46.2 \mathrm{mV}), \text { PEG }(-11.1 \mathrm{mV})\end{array}$ & HaCaT & $\begin{array}{l}\text { Mercaptohexadecanoic } \\
\text { acid > PEG }\end{array}$ & $\begin{array}{l}\text { Grabinski et al., } \\
2011\end{array}$ \\
\hline Silica & $50 \mathrm{~nm}$ & $\begin{array}{l}\mathrm{NH}_{2}(25 \mathrm{mV}), \mathrm{COOH}(-42 \mathrm{mV}), \mathrm{PEG} \\
(-29 \mathrm{mV})\end{array}$ & RAW264.7 & $\mathrm{COOH}>\left(\mathrm{NH}_{2}, \mathrm{PEG}\right)$ & $\begin{array}{l}\text { Kurtz-Chalot et al., } \\
2017\end{array}$ \\
\hline $\begin{array}{l}\mathrm{TiO}_{2} \\
\text { nanowires }\end{array}$ & $\begin{array}{l}\text { Diameter: } \\
\text { 200-400 nm }\end{array}$ & -1.6 to $-15.9 \mathrm{mV}$ & Mice & $\begin{array}{l}\text { Positively correlated with } \\
\text { zeta potential }\end{array}$ & Park et al., 2013 \\
\hline $\mathrm{ZnO}$ & $100,130 \mathrm{~nm}$ & $\begin{array}{l}\text { Triethoxycaprylylsilane (hydrophobic, } \\
-16.67 \mathrm{mV}), \text { pristine }(-19.53 \mathrm{mV})\end{array}$ & $\begin{array}{l}\text { A549-macrophage } \\
\text { co-culture }\end{array}$ & $\begin{array}{l}\text { Triethoxycaprylylsilane }< \\
\text { pristine }\end{array}$ & Liu et al., 2019 \\
\hline Iron oxide & $10 \mathrm{~nm}$ & Pristine, PEG & A549 & Pristine $>$ PEG & Griffete et al., 2012 \\
\hline Carbon & $\begin{array}{l}\text { Diameter: } \\
\text { 60-200 }\end{array}$ & N.A. & $\begin{array}{l}\text { IC-21 murine } \\
\text { macrophages }\end{array}$ & Hydrophobic > hydrophilic & Chun et al., 2011 \\
\hline MWCNTS & $\begin{array}{l}\text { Diameter: } \\
\text { 20-30 nm }\end{array}$ & $\mathrm{COOH}$, pristine & HUVECs & Pristine $>\mathrm{COOH}$ & Long et al., 2018 \\
\hline MWCNTS & N.A. & $\begin{array}{l}\mathrm{COOH}(-13.8 \mathrm{mV}), \text { pristine } \\
(-9.76 \mathrm{mV})\end{array}$ & $\begin{array}{l}\text { C57Bl/6 alveolar } \\
\text { macrophage }\end{array}$ & Pristine $>\mathrm{COOH}$ & Hamilton et al., 2013 \\
\hline MWCNTS & $<500 \mathrm{~nm}$ & $\begin{array}{l}\text { Pristine }(-6.8 \mathrm{mV}), \mathrm{COOH}(-12.2 \text { to } \\
-32.2 \mathrm{mV})\end{array}$ & Mice & Pristine $>\mathrm{COOH}$ & Jain et al., 2011 \\
\hline MWCNTS & $\begin{array}{l}\text { Diameter: } \\
\text { 10-20 } \mathrm{nm} \text {, } \\
\text { length: } 5-15 \mu \mathrm{m}\end{array}$ & Pristine (-15.5 mV), PEG (-12.8 mV) & Mice & Pristine $>$ PEG & Zhang et al., 2017 \\
\hline Graphene & $\begin{array}{l}\text { Thickness: } \\
<5 \mathrm{~nm} \text {, } \\
\text { diameter: }<2 \mu \mathrm{m}\end{array}$ & $\mathrm{NH}_{2}(15.5 \mathrm{mV}), \mathrm{COOH}(-35 \mathrm{mV})$ & Rats & $\mathrm{NH}_{2}>\mathrm{COOH}$ & Lee et al., 2017 \\
\hline Graphene & $\begin{array}{l}\text { Lateral } \\
\text { dimension of } \\
\sim 100-200 \mathrm{~nm}\end{array}$ & $\mathrm{COOH}, \mathrm{PEG}$ & Mice & $\mathrm{COOH}>\mathrm{PEG}$ & $\begin{array}{l}\text { Sasidharan et al., } \\
2015\end{array}$ \\
\hline Liposome & $100-150 \mathrm{~nm}$ & Cationic, neutral, anionic ligand & Mice & Cationic > (neutral, anionic) & Wei et al., 2015 \\
\hline Lipid & $<200 \mathrm{~nm}$ & Cationic, anionic ligand & Rats & Cationic > anionic & Gabal et al., 2014 \\
\hline Nanogels & $50-60 \mathrm{~nm}$ & $\begin{array}{l}\text { PEG }(-2.46 \mathrm{mV}) \text {, poly(sulfobetaine) } \\
\text { (PSB, -2.01 mV), and } \\
\text { poly(carboxybetaine) (PCB, } \\
-1.89 \mathrm{mV})\end{array}$ & PBMCs & $(\mathrm{PSB}, \mathrm{PCB})>\mathrm{PEG}$ & Li et al., 2018 \\
\hline Polymer & $160 \mathrm{~nm}$ & Polyvinyl acetate (-3 mV) & Mice & $\begin{array}{l}\text { Positively correlated with } \\
\text { hydrophobicity }\end{array}$ & Dailey et al., 2015 \\
\hline Polymer & $20-25 \mathrm{~nm}$ & PEG (1.7 mV, $8.8 \mathrm{mV}, 15.4 \mathrm{mV})$ & Mice & $\begin{array}{l}\text { Negatively correlated with } \\
\text { PEG length }\end{array}$ & Ibricevic et al., 2013 \\
\hline
\end{tabular}

N.A., not available.

\section{Hydrophobicity}

Hydrophobic NPs are prone to inducing the release of cytokines. For example, in IC-21 murine macrophages, hydrophobic carbon fibers induced higher levels of IL- 6 and TNF- $\alpha$ secretion than did hydrophilic carbon fibers (Chun et al., 2011). Ligand hydrophobicity on GNPs $(2 \mathrm{~nm})$ could regulate the gene expression of pro-inflammatory cytokines, with hydrophobic GNPs inducing higher levels of TNF- $\alpha$ and IL-6 gene expression in splenocytes (Moyano et al., 2012). However, in another study, hydrophobic ZnO NPs (130 nm) elicited lower expression of ER stress-apoptosis genes compared to pristine $\mathrm{ZnO}$ NPs $(100 \mathrm{~nm})$ in A549-macrophage co-culture (Liu et al., 2019). Hydrophilic NPs could also alleviate inflammation. For example, three kinds of nanogels $(50-60 \mathrm{~nm}$ ) were synthesized with PEG, poly(sulfobetaine) (PSB), and poly(carboxybetaine) (PCB). PCB nanogels, which is the most hydrophilic, could efficiently alleviate inflammation responses induced by LPS, followed by PSB and PEG nanogels (Li et al., 2018).

In vivo experiments demonstrated that hydrophobic polymeric NPs $(160 \mathrm{~nm})$ could elicit inflammation in mice. 
TABLE 6 | Apoptosis regulated by NPs' surface chemistry.

\begin{tabular}{|c|c|c|c|c|c|}
\hline Composition & Size & $\begin{array}{l}\text { Surface chemistry/Zeta } \\
\text { potential/LogP }\end{array}$ & Cell line & Apoptosis & References \\
\hline Gold & $1.5 \mathrm{~nm}$ & $\begin{array}{l}\text { Trimethylammoniumethanethiol } \\
\text { (TMAT,), mercaptoethanesulfonate } \\
\text { (MES), mercaptoethoxyethoxyethanol } \\
\text { (MEEE) }\end{array}$ & HaCaT & (TMAT, MES) > MEEE & Schaeublin et al., 2011 \\
\hline Gold & $1-10 \mathrm{~nm}$ & $\begin{array}{l}\text { Poly(quaternary ammonium), sodium } \\
\text { polyacrylate }\end{array}$ & Human neutrophils & $\begin{array}{l}\text { Sodium polyacrylate> } \\
\text { poly(quaternary } \\
\text { ammonium) }\end{array}$ & Durocher et al., 2017 \\
\hline Gold & $20-25 \mathrm{~nm}$ & $\begin{array}{l}\text { Cysteamine conjugated cholic acid } \\
\text { (DCaC), dicationic cysteamine } \\
\text { conjugated deoxycholic acid } \\
\text { (DCaDC), dicationic cysteamine } \\
\text { conjugated lithocholic acid (DCaLC) }\end{array}$ & A549 & $\mathrm{DCaLC}>\mathrm{DCaDC}>\mathrm{DCaC}$ & $\begin{array}{l}\text { Muthukumarasamyvel } \\
\text { et al., } 2017\end{array}$ \\
\hline $\begin{array}{l}\text { Gold } \\
\text { nanowires }\end{array}$ & $\begin{array}{l}\text { Diameter: } \\
200 \mathrm{~nm}\end{array}$ & $\mathrm{NH}_{2}(11.4 \mathrm{mV}), \mathrm{COOH}(-25.5 \mathrm{mV})$ & Fibroblast, HeLa & $\mathrm{NH}_{2}>\mathrm{COOH}$ & Kuo et al., 2007 \\
\hline Graphene & $3.5-5 \mathrm{~nm}$ & $\mathrm{OH}, \mathrm{COOH}, \mathrm{NH}_{2}$ & A549 & $\mathrm{OH}>\left(\mathrm{COOH}, \mathrm{NH}_{2}\right)$ & Xie J. et al., 2019 \\
\hline Graphene & $200 \mathrm{~nm}$ & $\begin{array}{l}\text { PEI (40.4 mV), pristine }(-7.36 \mathrm{mV}) \\
\text { BSA }(-33.3 \mathrm{mV}), \text { PEG }(-18.3 \mathrm{mV})\end{array}$ & J774A.1 & $\mathrm{PEl}>$ the rest & Luo et al., 2015 \\
\hline Polystyene & $110 \mathrm{~nm}$ & $\mathrm{NH}_{2}, \mathrm{COOH}$ & $\begin{array}{l}\text { THP-1, differentiated } \\
\text { THP-1 }\end{array}$ & $\mathrm{NH}_{2}>\mathrm{COOH}$ & Loos et al., 2014 \\
\hline Polystyene & $60 \mathrm{~nm}$ & $\mathrm{NH}_{2}(40.3 \mathrm{mV}), \mathrm{COOH}(-27.6 \mathrm{mV})$ & RAW264.7 & $\mathrm{NH}_{2}>\mathrm{COOH}$ & Xia et al., 2006 \\
\hline Polystyene & $200 \mathrm{~nm}$ & $\mathrm{NH}_{2}$, PEG-NH & RAW264.7 & $\mathrm{NH}_{2}>\mathrm{PEG}-\mathrm{NH}_{2}$ & Lee K. et al., 2011 \\
\hline
\end{tabular}

The hydrophobicity of polymeric NPs was positively correlated with neutrophilia and pro-inflammatory cytokine levels (Dailey et al., 2015). Mice treated with hydrophobic pristine-MWCNTs induced inflammatory cell infiltration in the portal region of liver, however, hydrophilic f-MWCNTs induced slight or no inflammation in liver (Jain et al., 2011). PEG decoration can alleviate the inflammation induced by NPs. In HaCaT cells, GNRs $(35 \times 10 \mathrm{~nm})$ decorated with mercaptohexadecanoic acid upregulated the $I L-1 \alpha$ and Serpine1 genes, which corresponded to pro-inflammatory and anti-inflammatory effects, respectively. GNRs decorated with PEG had no impact on these genes (Grabinski et al., 2011). Both pristine and PEG-decorated iron oxide NPs $(10 \mathrm{~nm})$ could induce the release of proinflammatory chemokine IL-8 in A549 cells. The secretion level of IL-8 induced by PEG decoration was low compared to that induced by pristine iron oxide NPs (Griffete et al., 2012). In a 28 days repeated dose toxicity study, pristine-MWCNTs caused higher levels of inflammation in lung and liver of mice than PEG-MWCNTs (Zhang et al., 2017). Few-layer graphene (FLG, 2-4 layers, lateral dimension of $\sim 100-200 \mathrm{~nm}$ ) and FLG-COOH elicited acute and chronic lung inflammation in mice. PEG decoration on FLG could effectively alleviate lung inflammation (Sasidharan et al., 2015). In another in vivo study, it was also found that PEG decoration on shell-crosslinked-knedel-like NPs (20-25 nm) could ameliorate the acute inflammation in the lung, and the length of PEG chain was positively correlated with the anti-inflammatory effects (Ibricevic et al., 2013).

\section{Combinatorial Surface Modifications}

Based on a combinatorial MWCNT library, Gao et al found that surface chemistry on MWCNTs could tune the inflammatory response in vivo and in vitro. The in vivo experiments demonstrated that surface chemistry could regulate the IL-1 $\beta$ and TNF- $\alpha$ levels in the lung and liver. The in vitro experiments indicated that surface chemistry could steer macrophage recognition from the mannose receptor to the scavenger receptor, resulting in the alleviation of the NF- $\kappa \mathrm{B}$ pathway and proinflammatory chemokines (Gao et al., 2011).

\section{APOPTOSIS}

Apoptotic pathways could be classified into two types: extrinsic and intrinsic pathways. Extrinsic apoptotic pathways could be triggered through the activation of the death receptor superfamily proteins, including CD95 and tumor necrosis factor receptor I. Intrinsic apoptotic pathways are primarily mediated through the mitochondria or the endoplasmic reticulum (Hengartner, 2000; Szegezdi et al., 2006).

There are many approaches to determining apoptosis. For example, the expression level of proapoptotic and antiapoptotic genes can be determined by RT-PCR (Cho et al., 2009b; Schaeublin et al., 2012). Western blotting and immunofluorescence can be used to determine the expression level of proapoptotic and antiapoptotic proteins (Hengartner, 2000). TEM images can also provide apoptosisrelated information at the cell level (Elmore, 2007). In this section, we summarize recently published literatures related to the regulation of apoptosis by NPs' surface charge and hydrophobicity (Table 6).

\section{Surface Charge}

Positively and negatively charged GNPs $(1.5 \mathrm{~nm})$ increased the expression of caspase- 3 and led to the apoptosis of $\mathrm{HaCaT}$ 


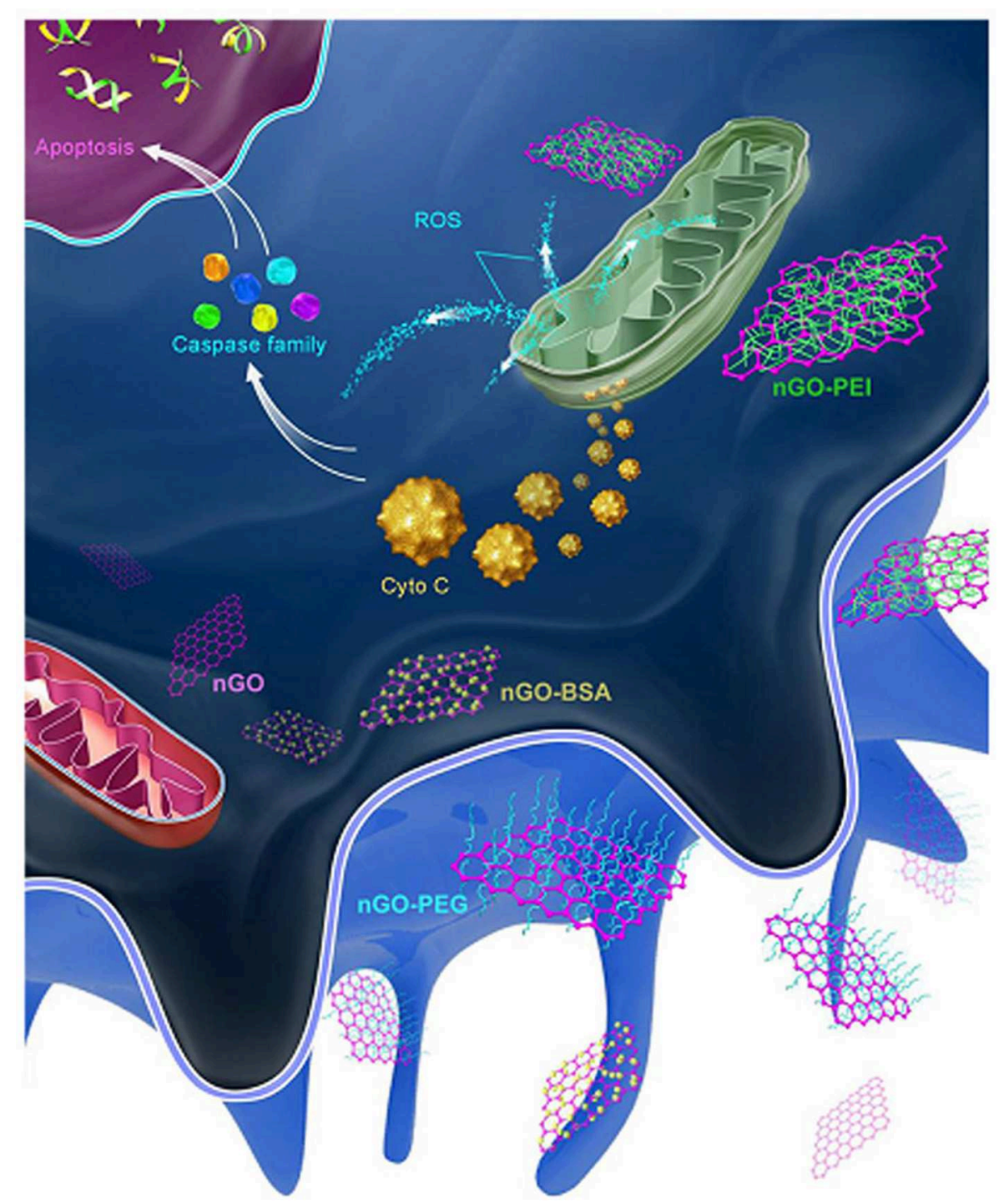

FIGURE 7 | After being phagocytized, PEI-GO was more apt to interact with mitochondria and activate the apoptotic pathway. Reproduced with permission from Luo et al. (2015).

cells, while neutrally charged GNPs induced necrosis instead of apoptosis (Schaeublin et al., 2011). In another study, negatively charged GNPs $(1-10 \mathrm{~nm})$ induced apoptosis in freshly isolated human neutrophils, while positively charged GNPs did not elicit apoptosis (Durocher et al., 2017). In fibroblast and HeLa cells, positively charged gold nanowires (diameter: $200 \mathrm{~nm}$ ) induced greater cytotoxicity than negatively charged counterparts (Kuo et al., 2007).

GQDs $(3.5-5 \mathrm{~nm})$ with different surface charges can tune apoptosis in A549 cells. Neutrally charged $\mathrm{OH}-$ GQDs induced higher levels of apoptosis than did either negatively charged COOH-GQDs or positively charged $\mathrm{NH}_{2}$-GQDs (Xie Y. et al., 2019). In J774A.1 macrophages, positively charged PEI-GO NPs induced the highest level of apoptosis, followed by pristine, BSA, and PEG decorated
GO NPs, which all had a negative zeta potential (Figure 7) (Luo et al., 2015).

In THP-1 and differentiated THP-1 cells, positively charged $\mathrm{NH}_{2}$-PS NPs $(110 \mathrm{~nm})$ induced apoptosis, while negatively charged COOH-PS NPs did not induce apoptosis (Loos et al., 2014). In RAW264.7 macrophages, $\mathrm{NH}_{2}$-PS NPs $(60 \mathrm{~nm})$ was found to elicit apoptosis, but not COOH-PS NPs (Xia et al., 2006). Therefore, on PS NPs, positively charged decorations are more likely to induce apoptosis than are negatively charged decorations.

\section{Hydrophobicity}

The hydrophobicity of GNPs $(20-25 \mathrm{~nm})$ could regulate apoptosis in A549 cells, with hydrophobic GNPs inducing higher levels of apoptosis than induced by hydrophilic GNPs 


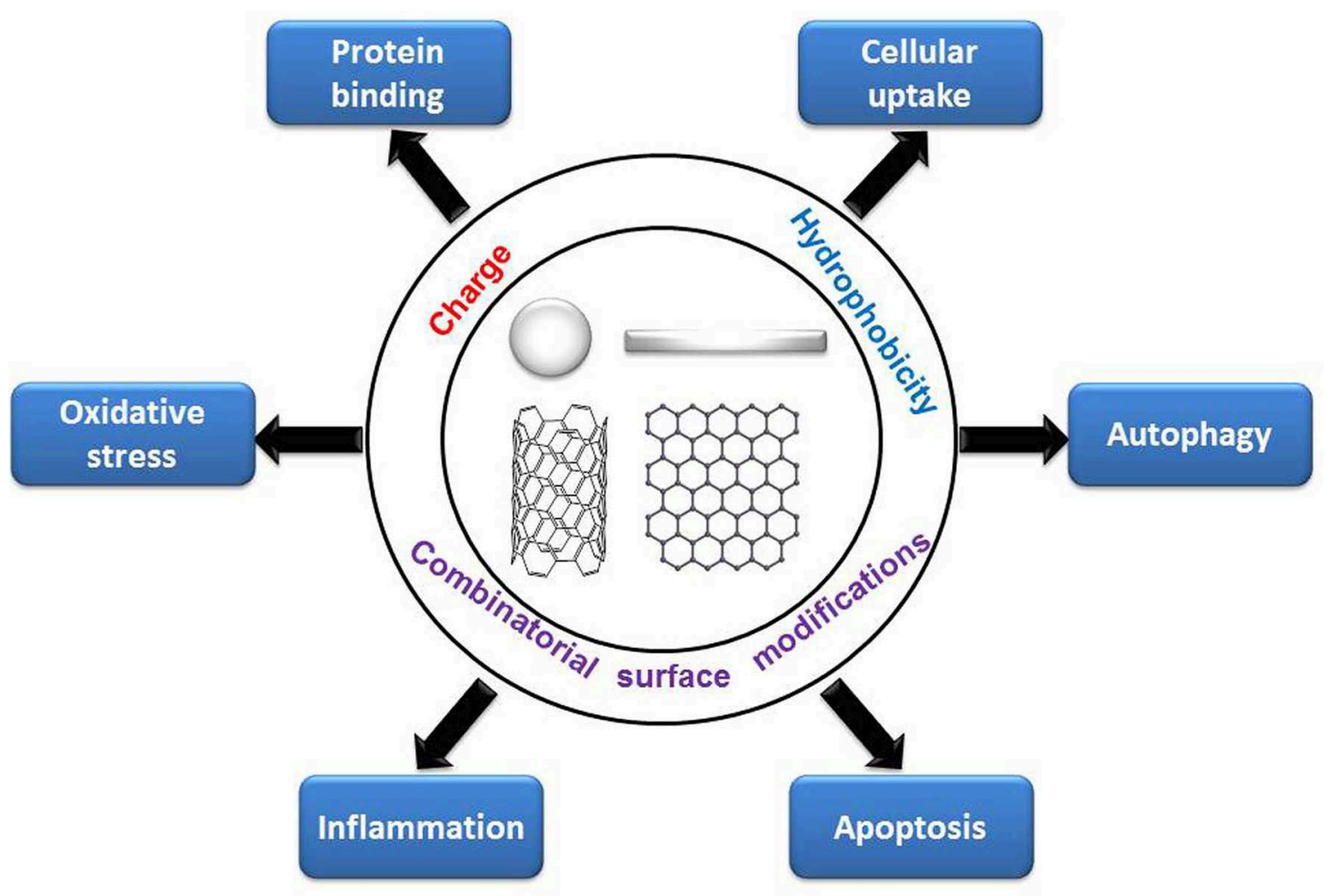

FIGURE 8 | Regulation of cytotoxicity-related bioeffects by surface chemistry.

(Muthukumarasamyvel et al., 2017). The apoptosis levels in RAW264.7 cells induced by $\mathrm{NH}_{2}$ - and PEG- $\mathrm{NH}_{2}-\mathrm{PS}$ NPs $(200 \mathrm{~nm})$ were compared. PEG decoration significantly reduced apoptosis levels compared to those of $\mathrm{NH}_{2}$-PS NPs $(200 \mathrm{~nm}$ ) in the RAW264.7 cells (Lee K. et al., 2011). However, in vivo experiments demonstrated that PEGdecorated NPs could also induce apoptosis. For example, PEG- GNPs $(4,100 \mathrm{~nm})$ induced apoptosis in liver tissue after intravenous administration to $\mathrm{BALB} / \mathrm{c}$ mice (Cho et al., $2009 b)$. In another paper, PEG- GNPs $(13 \mathrm{~nm})$ was found to accumulate in liver and induced apoptosis 7 days after injection (Cho et al., 2009a).

\section{SUMMARY AND PERSPECTIVE}

By summarizing recent literature, we found that the decoration of PEG, ligands of different charge and hydrophobicity, and combinatorial surface decoration could tune various cytotoxicity-related bioeffects. Generally, positively charged and hydrophobic NPs are more likely to be internalized by cells and induce oxidative stress, autophagy, and apoptosis than are negatively charged or hydrophilic NPs, and negatively charged NPs are more likely to adsorb proteins than are positively charged NPs. PEG decoration on NPs can alleviate these cytotoxicity-related bioeffects (Figure 8). Adding combinatorial surface decoration was proven to be an effective strategy to reveal the impact of various types of surface chemistry on bioeffects.

In addition to the bio-effect levels, molecular pathways can also be regulated by surface chemistry, especially for differently charged, hydrophobic, and combinatorial surface decorations. In our study, we found that oxidative stress induced by positively charged and hydrophobic GNPs is endocytosis-dependent. The endocytosis of positively charged and hydrophobic GNPs elicited oxidative stress through different signaling pathways, including elevated calcium level, activation of mitochondria and NADPH oxidase. Moreover, oxidative stress is considered to be an important upstream mechanism that positively regulate autophagy, inflammation, and apoptosis (Circu and Aw, 2010; Reuter et al., 2010; Lee J. et al., 2011). Given that surface charge and hydrophobicity are non-specific interactions between NPs and biomolecules (Kim et al., 2013; Nam et al., 2013), binding of specific key proteins may not be the main mechanism for surface charge or hydrophobicity induced cytotoxicity response. From the published papers, we can see that the mechanism is complicated, from affecting the protein binding, the internalization pathways and subcellular localization of NPs to the interaction with the cell membrane, lipids, proteins, and DNA, and the induction of oxidative stress as well.

For NPs of different compositions, sizes and shapes, the rules by which surface chemistry regulates bioeffects are sometimes inconsistent. Moreover, the surface chemistry modulation of bioeffects sometimes varies by cell line. Therefore, caution should 
be exercised when extrapolating conclusions obtained from a certain sized, shaped, or composited NP and/or a cell line.

\section{AUTHOR CONTRIBUTIONS}

HS and SZ designed this work of review and revised the manuscript. HS, CJ, LW, and XB performed the literature search

\section{REFERENCES}

Abdelkhaliq, A., Van Der Zande, M., Punt, A., Helsdingen, R., Boeren, S., Vervoort, J. J. M., et al. (2018). Impact of nanoparticle surface functionalization on the protein corona and cellular adhesion, uptake and transport. J. Nanobiotechnol. 16:70. doi: 10.1186/s12951-018-0394-6

Albanese, A., Tang, P. S., and Chan, W. C. (2012). The effect of nanoparticle size, shape, and surface chemistry on biological systems. Annu. Rev. Biomed. Eng. 14, 1-16. doi: 10.1146/annurev-bioeng-071811-150124

Aramesh, M., Shimoni, O., Ostrikov, K., Prawer, S., and Cervenka, J. (2015). Surface charge effects in protein adsorption on nanodiamonds. Nanoscale 7, 5726-5736. doi: 10.1039/C5NR00250H

Asharani, P. V., Low Kah Mun, G., Hande, M. P., and Valiyaveettil, S. (2009). Cytotoxicity and genotoxicity of silver nanoparticles in human cells. Acs Nano 3, 279-290. doi: 10.1021/nn800596w

Ayala, V., Herrera, A. P., Latorre-Esteves, M., Torres-Lugo, M., and Rinaldi, C. (2013). Effect of surface charge on the colloidal stability and in vitro uptake of carboxymethyl dextran-coated iron oxide nanoparticles. J Nanopart. Res. 15:1874. doi: 10.1007/s11051-013-1874-0

Bartczak, D., Baradez, M. O., Goenaga-Infante, H., and Marshall, D. (2015). Label-free monitoring of the nanoparticle surface modification effects on cellular uptake, trafficking and toxicity. Toxicol. Res. 4, 169-176. doi: 10.1039/C4TX00105B

Bartneck, M., Keul, H. A., Singh, S., Czaja, K., Bornemann, J., Bockstaller, M., et al. (2010). Rapid uptake of gold nanorods by primary human blood phagocytes and immunomodulatory effects of surface chemistry. ACS Nano 4, 3073-3086. doi: $10.1021 / \mathrm{nn} 100262 \mathrm{~h}$

Beck, M., Mandal, T., Buske, C., and Lindén, M. (2017). Serum protein adsorption enhances active leukemia stem cell targeting of mesoporous silica nanoparticles. ACS Appl. Mater. Interfaces 9, 18566-18574. doi: 10.1021/acsami.7b04742

Bedard, K., and Krause, K. H. (2007). The NOX family of ROS-generating NADPH oxidases: physiology and pathophysiology. Physiol. Rev. 87, 245-313. doi: 10.1152/physrev.00044.2005

Bogdanov, A. A., Gupta, S., Koshkina, N., Corr, S. J., Zhang, S., Curley, S. A., et al. (2015). Gold nanoparticles stabilized with MPEG-grafted Poly(l-lysine): in vitro and in vivo evaluation of a potential theranostic agent. Bioconjug. Chem. 26, 39-50. doi: 10.1021/bc5005087

Braun, N. J., Debrosse, M. C., Hussain, S. M., and Comfort, K. K. (2016). Modification of the protein corona-nanoparticle complex by physiological factors. Mater. Sci. Eng. C 64, 34-42. doi: 10.1016/j.msec.2016.03.059

Budhathoki-Uprety, J., Harvey, J. D., Isaac, E., Williams, R. M., Galassi, T. V., Langenbacher, R. E., et al. (2017). Polymer cloaking modulates the carbon nanotube protein corona and delivery into cancer cells. J. Mater. Chem. B 5, 6637-6644. doi: 10.1039/C7TB00695K

Bystrzejewska-Piotrowska, G., Golimowski, J., and Urban, P. L. (2009). Nanoparticles: their potential toxicity, waste and environmental management. Waste Manage. 29, 2587-2595. doi: 10.1016/j.wasman.2009.04.001

Cedervall, T., Lynch, I., Lindman, S., Berggård, T., Thulin, E., Nilsson, H., et al. (2007). Understanding the nanoparticle-protein corona using methods to quantify exchange rates and affinities of proteins for nanoparticles. Proc. Natl. Acad. Sci. U.S.A. 104:2050. doi: 10.1073/pnas.0608582104

Chakraborty, A., and Jana, N. R. (2015). Clathrin to lipid raft-endocytosis via controlled surface chemistry and efficient perinuclear targeting of nanoparticle. J. Phys. Chem. Lett. 6, 3688-3697. doi: 10.1021/acs.jpclett.5b01739 of the databases. HS, CJ, LW, XB, and SZ wrote the manuscript. All authors approved the paper for publication.

\section{FUNDING}

This work was supported by the National Natural Science Foundation of China (21677090).

Chandran, P., Riviere, J. E., and Monteiro-Riviere, N. A. (2017). Surface chemistry of gold nanoparticles determines the biocorona composition impacting cellular uptake, toxicity and gene expression profiles in human endothelial cells. Nanotoxicology 11, 507-519. doi: 10.1080/17435390.2017.1314036

Chen, G., Roy, I., Yang, C., and Prasad, P. N. (2016). Nanochemistry and nanomedicine for nanoparticle-based diagnostics and therapy. Chem. Rev. 116, 2826-2885. doi: 10.1021/acs.chemrev.5b00148

Chen, Y., Yang, L., Feng, C., and Wen, L.-P. (2005). Nano neodymium oxide induces massive vacuolization and autophagic cell death in non-small cell lung cancer NCI-H460 cells. Biochem. Biophys. Res. Commun. 337, 52-60. doi: 10.1016/j.bbrc.2005.09.018

Chen, Y.-P., Wu, S.-H., Chen, I. C., and Chen, C.-T. (2017). Impacts of crosslinkers on biological effects of mesoporous silica nanoparticles. ACS Appl. Mater. Interfaces 9, 10254-10265. doi: 10.1021/acsami.7b00240

Cho, E. C., Au, L., Zhang, Q., and Xia, Y. (2010). The effects of size, shape, and surface functional group of gold nanostructures on their adsorption and internalization by cells. Small 6, 517-522. doi: 10.1002/smll.200901622

Cho, W.-S., Cho, M., Jeong, J., Choi, M., Cho, H.-Y., Han, B. S., et al. (2009a). Acute toxicity and pharmacokinetics of $13 \mathrm{~nm}$-sized PEG-coated gold nanoparticles. Toxicol. Appl. Pharmacol. 236, 16-24. doi: 10.1016/j.taap.2008.12.023

Cho, W.-S., Kim, S., Han, B. S., Son, W. C., and Jeong, J. (2009b). Comparison of gene expression profiles in mice liver following intravenous injection of 4 and 100nm-sized PEG-coated gold nanoparticles. Toxicol. Lett. 191, 96-102. doi: 10.1016/j.toxlet.2009.08.010

Chompoosor, A., Saha, K., Ghosh, P. S., Macarthy, D. J., Miranda, O. R., Zhu, Z.-J., et al. (2010). the role of surface functionality on acute cytotoxicity, ROS generation and DNA damage by cationic gold nanoparticles. Small 6, 2246-2249. doi: 10.1002/smll.201000463

Chun, Y. W., Wang, W., Choi, J., Nam, T.-H., Lee, Y.-H., Cho, K.-K., et al. (2011). Control of macrophage responses on hydrophobic and hydrophilic carbon nanostructures. Carbon 49, 2092-2103. doi: 10.1016/j.carbon.2011. 01.044

Circu, M. L., and Aw, T. Y. (2010). Reactive oxygen species, cellular redox systems, and apoptosis. Free Radic. Biol. Med. 48, 749-762. doi: 10.1016/j.freeradbiomed.2009.12.022

Dailey, L. A., Hernández-Prieto, R., Casas-Ferreira, A. M., Jones, M.-C., RiffoVasquez, Y., Rodríguez-Gonzalo, E., et al. (2015). Adenosine monophosphate is elevated in the bronchoalveolar lavage fluid of mice with acute respiratory toxicity induced by nanoparticles with high surface hydrophobicity. Nanotoxicology 9, 106-115. doi: 10.3109/17435390.2014.894150

De Castro, C. E., Ribeiro, C. A. S., Alavarse, A. C., Albuquerque, L. J. C., Da Silva, M. C. C., Jäger, E., et al. (2018). Nanoparticle-cell interactions: surface chemistry effects on the cellular uptake of biocompatible block copolymer assemblies. Langmuir 34, 2180-2188. doi: 10.1021/acs.langmuir.7b04040

De Volder, M. F., Tawfick, S. H., Baughman, R. H., and Hart, A. J. (2013). Carbon nanotubes: present and future commercial applications. Science 339:535. doi: $10.1126 /$ science. 1222453

Deng, Z. J., Liang, M., Toth, I., Monteiro, M., and Minchin, R. F. (2012). Plasma protein binding of positively and negatively charged polymer-coated gold nanoparticles elicits different biological responses. Nanotoxicology 7, 314-322. doi: 10.3109/17435390.2012.655342

Dumontel, B., Canta, M., Engelke, H., Chiodoni, A., Racca, L., Ancona, A., et al. (2017). Enhanced biostability and cellular uptake of zinc oxide nanocrystals shielded with a phospholipid bilayer. J. Mater. Chem. B 5, 8799-8813. doi: 10.1039/C7TB02229H 
Durocher, I., Noël, C., Lavastre, V., and Girard, D. (2017). Evaluation of the in vitro and in vivo proinflammatory activities of gold $(+)$ and gold $(-)$ nanoparticles. Inflammation Res. 66, 981-992. doi: 10.1007/s00011-017-1078-7

Elmore, S. (2007). Apoptosis: a review of programmed cell death. Toxicol. Pathol. 35, 495-516. doi: 10.1080/01926230701320337

Foldbjerg, R., Dang, D. A., and Autrup, H. (2011). Cytotoxicity and genotoxicity of silver nanoparticles in the human lung cancer cell line, A549. Arch. Toxicol. 85, 743-750. doi: 10.1007/s00204-010-0545-5

Freese, C., Gibson, M. I., Klok, H.-A., Unger, R. E., and Kirkpatrick, C. J. (2012). Size- and coating-dependent uptake of polymer-coated gold nanoparticles in primary human dermal microvascular endothelial cells. Biomacromolecules 13, 1533-1543. doi: 10.1021/bm300248u

Gabal, Y. M., Kamel, A. O., Sammour, O. A., and Elshafeey, A. H. (2014). Effect of surface charge on the brain delivery of nanostructured lipid carriers in situ gels via the nasal route. Int. J. Pharmaceut. 473, 442-457. doi: 10.1016/j.ijpharm.2014.07.025

Gao, N., Zhang, Q., Mu, Q., Bai, Y., Li, L., Zhou, H., et al. (2011). Steering carbon nanotubes to scavenger receptor recognition by nanotube surface chemistry modification partially alleviates NFKB activation and reduces its immunotoxicity. ACS Nano 5, 4581-4591. doi: 10.1021/nn200283g

Ge, C., Du, J., Zhao, L., Wang, L., Liu, Y., Li, D., et al. (2011). Binding of blood proteins to carbon nanotubes reduces cytotoxicity. Proc. Natl. Acad. Sci. U.S.A. 108:16968. doi: 10.1073/pnas.1105270108

Grabinski, C., Schaeublin, N., Wijaya, A., D'couto, H., Baxamusa, S. H., HamadSchifferli, K., et al. (2011). Effect of gold nanorod surface chemistry on cellular response. ACS Nano 5, 2870-2879. doi: 10.1021/nn103476x

Griffete, N., Clift, M. J. D., Lamouri, A., Digigow, R. G., Mihut, A. M., Fink, A., et al. (2012). Amino covalent binding approach on iron oxide nanoparticle surface: toward biological applications. Colloids Surf. A Physicochem. Eng. Aspects 415, 98-104. doi: 10.1016/j.colsurfa.2012.09.020

Hamilton, R. F., Xiang, C., Li, M., Ka, I., Yang, F., Ma, D., et al. (2013). Purification and sidewall functionalization of multiwalled carbon nanotubes and resulting bioactivity in two macrophage models. Inhalat. Toxicol. 25, 199-210. doi: 10.3109/08958378.2013.775197

Hengartner, M. O. (2000). The biochemistry of apoptosis. Nature 407, 770-776. doi: $10.1038 / 35037710$

Hillaireau, H., and Couvreur, P. (2009). Nanocarriers' entry into the cell: relevance to drug delivery. Cell. Mol. Life Sci. 66, 2873-2896. doi: 10.1007/s00018-009-0053-z

Hu, W., Peng, C., Lv, M., Li, X., Zhang, Y., Chen, N., et al. (2011). Protein coronamediated mitigation of cytotoxicity of graphene oxide. ACS Nano 5, 3693-3700. doi: $10.1021 / \mathrm{nn} 200021 \mathrm{j}$

Ibricevic, A., Guntsen, S. P., Zhang, K., Shrestha, R., Liu, Y., Sun, J. Y., et al. (2013). PEGylation of cationic, shell-crosslinked-knedel-like nanoparticles modulates inflammation and enhances cellular uptake in the lung. Nanomed. Nanotechnol. Biol. Med. 9, 912-922. doi: 10.1016/j.nano.2013.02.006

Jain, S., Thakare, V. S., Das, M., Godugu, C., Jain, A. K., Mathur, R., et al. (2011). Toxicity of multiwalled carbon nanotubes with end defects critically depends on their functionalization density. Chem. Res. Toxicol. 24, 2028-2039. doi: $10.1021 /$ tx2003728

Jedlovszky-Hajdú, A., Bombelli, F. B., Monopoli, M. P., Tombácz, E., and Dawson, K. A. (2012). Surface coatings shape the protein corona of SPIONs with relevance to their application in vivo. Langmuir 28, 14983-14991. doi: 10.1021/la302446h

Jenkins, S. I., Weinberg, D., Al-Shakli, A. F., Fernandes, A. R., Yiu, H. H. P., Telling, N. D., et al. (2016). 'Stealth' nanoparticles evade neural immune cells but also evade major brain cell populations: implications for PEG-based neurotherapeutics. J. Controlled Release 224, 136-145. doi: 10.1016/j.jconrel.2016.01.013

Jiang, B., Wu, Q., Deng, N., Chen, Y., Zhang, L., Liang, Z., et al. (2016). Hydrophilic $\mathrm{GO} / \mathrm{Fe} 3 \mathrm{O} 4 / \mathrm{Au} / \mathrm{PEG}$ nanocomposites for highly selective enrichment of glycopeptides. Nanoscale 8, 4894-4897. doi: 10.1039/C5NR08126B

Jiang, Y., Huo, S., Mizuhara, T., Das, R., Lee, Y.-W., Hou, S., et al. (2015). The Interplay of size and surface functionality on the cellular uptake of sub-10 nm gold nanoparticles. ACS Nano 9, 9986-9993. doi: 10.1021/acsnano.5b03521

Jing, B., and Zhu, Y. (2011). Disruption of supported lipid bilayers by semihydrophobic nanoparticles. J. Am. Chem. Soc. 133, 10983-10989. doi: $10.1021 /$ ja2040305
Johnston, B. D., Kreyling, W. G., Pfeiffer, C., Schäffler, M., Sarioglu, H., Ristig, S., et al. (2017). Colloidal stability and surface chemistry are key factors for the composition of the protein corona of inorganic gold nanoparticles. Adv. Func. Mater. 27:1701956. doi: 10.1002/adfm.201701956

Karlsson, H. L., Cronholm, P., Gustafsson, J., and Möller, L. (2008). Copper oxide nanoparticles are highly toxic: a comparison between metal oxide nanoparticles and carbon nanotubes. Chem. Res. Toxicol. 21, 1726-1732. doi: $10.1021 /$ tx800064j

Karmali, P. P., and Simberg, D. (2011). Interactions of nanoparticles with plasma proteins: implication on clearance and toxicity of drug delivery systems. Expert Opin. Drug Deliv. 8, 343-357. doi: 10.1517/17425247.2011.554818

Keleştemur, S., Altunbek, M., and Culha, M. (2017). Influence of EDC/NHS coupling chemistry on stability and cytotoxicity of $\mathrm{ZnO}$ nanoparticles modified with proteins. Appl. Surf. Sci. 403, 455-463. doi: 10.1016/j.apsusc.2017.01.235

Kendall, M., Hodges, N. J., Whitwell, H., Tyrrell, J., and Cangul, H. (2015). Nanoparticle growth and surface chemistry changes in cellconditioned culture medium. Philos. Trans. R. Soc. B Biol. Sci. 370:20140100. doi: 10.1098/rstb.2014.0100

Kim, S. T., Saha, K., Kim, C., and Rotello, V. M. (2013). The role of surface functionality in determining nanoparticle cytotoxicity. Accounts Chem. Res. 46, 681-691. doi: 10.1021/ar3000647

Kleemann, E., Neu, M., Jekel, N., Fink, L., Schmehl, T., Gessler, T., et al. (2005). Nano-carriers for DNA delivery to the lung based upon a TAT-derived peptide covalently coupled to PEG-PEI. J. Controlled Release 109, 299-316. doi: 10.1016/j.jconrel.2005.09.036

Kokkinopoulou, M., Simon, J., Landfester, K., Mailänder, V., and Lieberwirth, I. (2017). Visualization of the protein corona: towards a biomolecular understanding of nanoparticle-cell-interactions. Nanoscale 9, 8858-8870. doi: 10.1039/C7NR02977B

Kuo, C. W., Lai, J. J., Wei, K. H., and Chen, P. (2007). Studies of surfacemodified gold nanowires inside living cells. Adv. Func. Mater. 17, 3707-3714. doi: 10.1002/adfm.200601133

Kurtz-Chalot, A., Villiers, C., Pourchez, J., Boudard, D., Martini, M., Marche, P. N., et al. (2017). Impact of silica nanoparticle surface chemistry on protein corona formation and consequential interactions with biological cells. Mater. Sci. Eng. C 75, 16-24. doi: 10.1016/j.msec.2017.02.028

Lammel, T., Boisseaux, P., Fernández-Cruz, M.-L., and Navas, J. M. (2013). Internalization and cytotoxicity of graphene oxide and carboxyl graphene nanoplatelets in the human hepatocellular carcinoma cell line Hep G2. Particle Fibre Toxicol. 10:27. doi: 10.1186/1743-8977-10-27

Lane, L. A., Qian, X., and Nie, S. (2015). SERS nanoparticles in medicine: from label-free detection to spectroscopic tagging. Chem. Rev. 115, 10489-10529. doi: 10.1021/acs.chemrev.5b00265

Larson, T. A., Joshi, P. P., and Sokolov, K. (2012). Preventing protein adsorption and macrophage uptake of gold nanoparticles via a hydrophobic shield. ACS Nano 6, 9182-9190. doi: 10.1021/nn3035155

Lee, J., Giordano, S., and Zhang, J. (2011). Autophagy, mitochondria and oxidative stress: cross-talk and redox signalling. Biochem. J. 441, 523-540. doi: 10.1042/BJ20111451

Lee, J. K., Jeong, A. Y., Bae, J., Seok, J. H., Yang, J.-Y., Roh, H. S., et al. (2017). The role of surface functionalization on the pulmonary inflammogenicity and translocation into mediastinal lymph nodes of graphene nanoplatelets in rats. Arch. Toxicol. 91, 667-676. doi: 10.1007/s00204-016-1706-y

Lee, K., Lee, H., Lee, K. W., and Park, T. G. (2011). Optical imaging of intracellular reactive oxygen species for the assessment of the cytotoxicity of nanoparticles. Biomaterials 32, 2556-2565. doi: 10.1016/j.biomaterials.2010.11.072

Leroueil, P. R., Berry, S. A., Duthie, K., Han, G., Rotello, V. M., Mcnerny, D. Q., et al. (2008). Wide varieties of cationic nanoparticles induce defects in supported lipid bilayers. Nano Lett. 8, 420-424. doi: 10.1021/nl0722929

Lesniak, A., Salvati, A., Santos-Martinez, M. J., Radomski, M. W., Dawson, K. A., and Åberg, C. (2013). Nanoparticle adhesion to the cell membrane and its effect on nanoparticle uptake efficiency. J. Am. Chem. Soc. 135, 1438-1444. doi: $10.1021 /$ ja309812z

Levine, B., and Kroemer, G. (2008). Autophagy in the pathogenesis of disease. Cell 132, 27-42. doi: 10.1016/j.cell.2007.12.018

Li, B., Xie, J., Yuan, Z., Jain, P., Lin, X., Wu, K., et al. (2018). Mitigation of inflammatory immune responses with hydrophilic nanoparticles. Angew. Chem. 130, 4617-4621. doi: 10.1002/ange.201710068 
Li, S., Zhai, S., Liu, Y., Zhou, H., Wu, J., Jiao, Q., et al. (2015a). Experimental modulation and computational model of nano-hydrophobicity. Biomaterials 52, 312-317. doi: 10.1016/j.biomaterials.2015.02.043

Li, S., Zhang, C., Cao, W., Ma, B., Ma, X., Jin, S., et al. (2015b). Anchoring effects of surface chemistry on gold nanorods: modulating autophagy. J. Mater. Chem. B 3, 3324-3330. doi: 10.1039/C5TB00076A

Li, Z., Gan, Q., Zhang, W., Zhang, J., Yuan, Y., and Liu, C. (2013). Surfaceinduced conformational and functional changes of bone morphogenetic protein-2 adsorbed onto single-walled carbon nanotubes. Biochem. Biophys. Res. Commun. 440, 215-221. doi: 10.1016/j.bbrc.2013.09.036

Lim, B., Jiang, M., Tao, J., Camargo, P. H. C., Zhu, Y., and Xia, Y. (2009). Shapecontrolled synthesis of Pd nanocrystals in aqueous solutions. Adv. Func. Mater. 19, 189-200. doi: 10.1002/adfm.200801439

Lin, J., Zhang, H., Chen, Z., and Zheng, Y. (2010). Penetration of Lipid Membranes by Gold Nanoparticles: Insights into Cellular Uptake, Cytotoxicity, and Their Relationship. Acs Nano 4, 5421-5429. doi: 10.1021/nn1010792

Liu, H. L., Zhang, Y. L., Yang, N., Zhang, Y. X., Liu, X. Q., Li, C. G., et al. (2011). A functionalized single-walled carbon nanotube-induced autophagic cell death in human lung cells through Akt-TSC2-mTOR signaling. Cell Death Dis. 2, e159-e159. doi: 10.1038/cddis.2011.27

Liu, T., Liang, H., Liu, L., Gong, Y., Ding, Y., Liao, G., et al. (2019). Influence of pristine and hydrophobic $\mathrm{ZnO}$ nanoparticles on cytotoxicity and endoplasmic reticulum (ER) stress-autophagy-apoptosis gene expression in A549-macrophage co-culture. Ecotoxicol. Environ. Saf. 167, 188-195. doi: 10.1016/j.ecoenv.2018.10.018

Liu, T.-P., Wu, S.-H., Chen, Y.-P., Chou, C.-M., and Chen, C.-T. (2015). Biosafety evaluations of well-dispersed mesoporous silica nanoparticles: towards in vivorelevant conditions. Nanoscale 7, 6471-6480. doi: 10.1039/C4NR07421A

Liu, Y., Winkler, D. A., Epa, V. C., Zhang, B., and Yan, B. (2015). Probing enzymenanoparticle interactions using combinatorial gold nanoparticle libraries. Nano Res. 8, 1293-1308. doi: 10.1007/s12274-014-0618-5

Liu, Z., Wang, L., Zhang, L., Wu, X., Nie, G., Chen, C., et al. (2016). Metabolic characteristics of $16 \mathrm{HBE}$ and A549 cells exposed to different surface modified gold nanorods. Adv. Healthcare Mater. 5, 2363-2375. doi: 10.1002/adhm.201600164

Long, J., Li, X., Kang, Y., Ding, Y., Gu, Z., and Cao, Y. (2018). Internalization, cytotoxicity, oxidative stress and inflammation of multi-walled carbon nanotubes in human endothelial cells: influence of pre-incubation with bovine serum albumin. RSC Adv. 8, 9253-9260. doi: 10.1039/C8RA00445E

Loos, C., Syrovets, T., Musyanovych, A., Mailänder, V., Landfester, K., Nienhaus, G. U., et al. (2014). Functionalized polystyrene nanoparticles as a platform for studying bio-nano interactions. Beilstein J Nanotechnol. 5, 2403-2412. doi: 10.3762/bjnano. 5.250

Lundqvist, M., Stigler, J., Elia, G., Lynch, I., Cedervall, T., and Dawson, K. A. (2008). Nanoparticle size and surface properties determine the protein corona with possible implications for biological impacts. Proc. Natl. Acad. Sci. U.S.A. 105, 14265. doi: 10.1073/pnas.0805135105

Lunov, O., Syrovets, T., Loos, C., Beil, J., Delacher, M., Tron, K., et al. (2011). Differential uptake of functionalized polystyrene nanoparticles by human macrophages and a monocytic cell line. ACS Nano 5, 1657-1669. doi: $10.1021 / \mathrm{nn} 2000756$

Luo, M., Shen, C., Feltis, B. N., Martin, L. L., Hughes, A. E., Wright, P. F., et al. (2014). Reducing $\mathrm{ZnO}$ nanoparticle cytotoxicity by surface modification. Nanoscale 6, 5791-5798. doi: 10.1039/C4NR00458B

Luo, N., Ni, D., Yue, H., Wei, W., and Ma, G. (2015). Surface-engineered graphene navigate divergent biological outcomes toward macrophages. ACS Appl. Mater. Interfaces 7, 5239-5247. doi: 10.1021/am5084607

Mahmoud, K. A., Mena, J. A., Male, K. B., Hrapovic, S., Kamen, A., and Luong, J. H. (2010). Effect of surface charge on the cellular uptake and cytotoxicity of fluorescent labeled cellulose nanocrystals. ACS Appl. Mater. Interfaces 2, 2924-2932. doi: 10.1021/am1006222

Mahmoudi, M., Lynch, I., Ejtehadi, M. R., Monopoli, M. P., Bombelli, F. B., and Laurent, S. (2011). Protein-nanoparticle interactions: opportunities and challenges. Chem. Rev. 111, 5610-5637. doi: 10.1021/cr100440g

Manshian, B. B., Moyano, D. F., Corthout, N., Munck, S., Himmelreich, U., Rotello, V. M., et al. (2014). High-content imaging and gene expression analysis to study cell-nanomaterial interactions: the effect of surface hydrophobicity. Biomaterials 35, 9941-9950. doi: 10.1016/j.biomaterials.2014.08.031
Mekseriwattana, W., Srisuk, S., Kriangsaksri, R., Niamsiri, N., and Prapainop, K. (2019). The impact of serum proteins and surface chemistry on magnetic nanoparticle colloidal stability and cellular uptake in breast cancer cells. AAPS PharmSciTech 20:55. doi: 10.1208/s12249-018-1275-x

Mizushima, N., Levine, B., Cuervo, A. M., and Klionsky, D. J. (2008). Autophagy fights disease through cellular self-digestion. Nature 451, 1069-1075. doi: $10.1038 /$ nature 06639

Monopoli, M. P., Aberg, C., Salvati, A., and Dawson, K.A. (2012). Biomolecular coronas provide the biological identity of nanosized materials. Nature Nanotechnol. 7:779. doi: 10.1038/nnano.2012.207

Mortensen, N. P., Hurst, G. B., Wang, W., Foster, C. M., Nallathamby, P. D., and Retterer, S. T. (2013). Dynamic development of the protein corona on silica nanoparticles: composition and role in toxicity. Nanoscale 5, 6372-6380. doi: $10.1039 / \mathrm{c} 3 \mathrm{nr} 33280 \mathrm{~b}$

Moyano, D. F., Goldsmith, M., Solfiell, D. J., Landesman-Milo, D., Miranda, O. R., Peer, D., et al. (2012). Nanoparticle hydrophobicity dictates immune response. J. Am. Chem. Soc. 134, 3965-3967. doi: 10.1021/ja2108905

Murphy, M. P. (2009). How mitochondria produce reactive oxygen species. Biochem. J. 417:1. doi: 10.1042/BJ20081386

Muthukumarasamyvel, T., Rajendran, G., Santhana Panneer, D., Kasthuri, J., Kathiravan, K., and Rajendiran, N. (2017). Role of surface hydrophobicity of dicationic amphiphile-stabilized gold nanoparticles on A549 lung cancer cells. ACS Omega 2, 3527-3538. doi: 10.1021/acsomega.7b00353

Nam, J., Won, N., Bang, J., Jin, H., Park, J., Jung, S., et al. (2013). Surface engineering of inorganic nanoparticles for imaging and therapy. Adv. Drug Deliv. Rev. 65, 622-648. doi: 10.1016/j.addr.2012.08.015

Nel, A., Xia, T., Mädler, L., and Li, N. (2006). Toxic potential of materials at the nanolevel. Science 311, 622-627. doi: 10.1126/science.1114397

Nguyen, K. C., Willmore, W. G., and Tayabali, A. F. (2013). Cadmium telluride quantum dots cause oxidative stress leading to extrinsic and intrinsic apoptosis in hepatocellular carcinoma HepG2 cells. Toxicology 306:114-123. doi: 10.1016/j.tox.2013.02.010

Nikoobakht, B., and El-Sayed, M. A. (2003). Preparation and growth mechanism of gold nanorods (NRs) using seed-mediated growth method. Chem. Mater. 15, 1957-1962. doi: 10.1021/cm020732l

Oh, N., and Park, J.-H. (2014). Surface chemistry of gold nanoparticles mediates their exocytosis in macrophages. ACS Nano 8, 6232-6241. doi: $10.1021 / \mathrm{nn} 501668 \mathrm{a}$

Ojea-Jiménez, I., Urbán, P., Barahona, F., Pedroni, M., Capomaccio, R., Ceccone, G., et al. (2016). Highly flexible platform for tuning surface properties of silica nanoparticles and monitoring their biological interaction. ACS Appl. Mater. Interfaces 8, 4838-4850. doi: 10.1021/acsami.5b11216

Orlando, A., Colombo, M., Prosperi, D., Gregori, M., Panariti, A., Rivolta, I., et al. (2015). Iron oxide nanoparticles surface coating and cell uptake affect biocompatibility and inflammatory responses of endothelial cells and macrophages. J. Nanopart. Res. 17:351. doi: 10.1007/s11051-0153148-5

Pang, C., Brunelli, A., Zhu, C., Hristozov, D., Liu, Y., Semenzin, E., et al. (2016). Demonstrating approaches to chemically modify the surface of Ag nanoparticles in order to influence their cytotoxicity and biodistribution after single dose acute intravenous administration. Nanotoxicology 10, 129-139. doi: 10.3109/17435390.2015.1024295

Park, C. S., Choi, K. S., Park, I. W., Jung, J. W., Choi, J. C., Kim, J. Y., et al. (2015). Autophagy in RAW264.7 cells treated with surface-functionalized graphene oxides. J. Nanomater. 2015, 1-8. doi: 10.1155/2015/704789

Park, E.-J., Shim, H.-W., Lee, G.-H., Kim, J.-H., and Kim, D.-W. (2013). Comparison of toxicity between the different-type $\mathrm{TiO} 2$ nanowires in vivo and in vitro. Arch. Toxicol. 87, 1219-1230. doi: 10.1007/s00204-013-1019-3

Park, J., Nam, J., Won, N., Jin, H., Jung, S., Jung, S., et al. (2011). Compact and stable quantum dots with positive, negative, or zwitterionic surface: specific cell interactions and non-specific adsorptions by the surface charges. Adv. Func. Mater. 21, 1558-1566. doi: 10.1002/adfm.201001924

Passagne, I., Morille, M., Rousset, M., Pujalté, I., and L’azou, B. (2012). Implication of oxidative stress in size-dependent toxicity of silica nanoparticles in kidney cells. Toxicology 299, 112-124. doi: 10.1016/j.tox.2012.05.010

Peng, L., Hu, L., and Fang, X. (2014). Energy harvesting for nanostructured self-powered photodetectors. Adv. Func. Mater. 24, 2591-2610. doi: 10.1002/adfm.201303367 
Piao, M. J., Kang, K. A., Lee, I. K., Kim, H. S., Kim, S., Choi, J. Y., et al. (2011). Silver nanoparticles induce oxidative cell damage in human liver cells through inhibition of reduced glutathione and induction of mitochondria-involved apoptosis. Toxicol. Lett. 201, 92-100. doi: 10.1016/j.toxlet.2010.12.010

Qiu, Y., Liu, Y., Wang, L., Xu, L., Bai, R., Ji, Y., et al. (2010). Surface chemistry and aspect ratio mediated cellular uptake of Au nanorods. Biomaterials 31, 7606-7619. doi: 10.1016/j.biomaterials.2010.06.051

Reuter, S., Gupta, S. C., Chaturvedi, M. M., and Aggarwal, B. B. (2010). Oxidative stress, inflammation, and cancer: how are they linked? Free Radic. Biol. Med. 49, 1603-1616. doi: 10.1016/j.freeradbiomed.2010.09.006

Ruenraroengsak, P., and Tetley, T. D. (2015). Differential bioreactivity of neutral, cationic and anionic polystyrene nanoparticles with cells from the human alveolar compartment: robust response of alveolar type 1 epithelial cells. Particle Fibre Toxicol. 12:19. doi: 10.1186/s12989-015-0091-7

Saha, K., Kim, S. T., Yan, B., Miranda, O. R., Alfonso, F. S., Shlosman, D., et al. (2013). Surface functionality of nanoparticles determines cellular uptake mechanisms in mammalian cells. Small 9, 300-305. doi: 10.1002/smll.201201129

Sahay, G., Alakhova, D. Y., and Kabanov, A. V. (2010). Endocytosis of nanomedicines. J. Controlled Release 145, 182-195. doi: $10.1016 /$ j.jconrel.2010.01.036

Sasidharan, A., Swaroop, S., Koduri, C. K., Girish, C. M., Chandran, P., Panchakarla, L. S., et al. (2015). Comparative in vivo toxicity, organ biodistribution and immune response of pristine, carboxylated and PEGylated few-layer graphene sheets in Swiss albino mice: a three month study. Carbon 95, 511-524. doi: 10.1016/j.carbon.2015.08.074

Schaeublin, N. M., Braydich-Stolle, L. K., Maurer, E. I., Park, K., Maccuspie, R. I., Afrooz, A. R., et al. (2012). Does shape matter? Bioeffects of gold nanomaterials in a human skin cell model. Langmuir 28, 3248-3258. doi: 10.1021/la204081m

Schaeublin, N. M., Braydich-Stolle, L. K., Schrand, A. M., Miller, J. M., Hutchison, J., Schlager, J. J., et al. (2011). Surface charge of gold nanoparticles mediates mechanism of toxicity. Nanoscale 3, 410-420. doi: 10.1039/c0nr00478b

Sheng, Y., Yuan, Y., Liu, C., Tao, X., Shan, X., and Xu, F. (2009). In vitro macrophage uptake and in vivo biodistribution of PLA-PEG nanoparticles loaded with hemoglobin as blood substitutes: effect of PEG content. J. Mater. Sci. Mater. Med. 20, 1881-1891. doi: 10.1007/s10856-009-3746-9

Shrestha, S., Mao, Z., Fedutik, Y., and Gao, C. (2016). Influence of titanium dioxide nanorods with different surface chemistry on the differentiation of rat bone marrow mesenchymal stem cells. J. Mater. Chem. B 4, 6955-6966. doi: 10.1039/C6TB02149B

Silvestri, A., Di Silvio, D., Llarena, I., Murray, R. A., Marelli, M., Lay, L., et al. (2017). Influence of surface coating on the intracellular behaviour of gold nanoparticles: a fluorescence correlation spectroscopy study. Nanoscale 9, 14730-14739. doi: 10.1039/C7NR04640E

Solarska-Sciuk, K., Gajewska, A., Glinska, S., Michlewska, S., Balcerzak, Ł., Jamrozik, A., et al. (2014). Effect of functionalized and non-functionalized nanodiamond on the morphology and activities of antioxidant enzymes of lung epithelial cells (A549). Chem. Biol. Interact. 222, 135-147. doi: $10.1016 /$ j.cbi.2014.10.003

Srivastava, I., Misra, S. K., Ostadhossein, F., Daza, E., Singh, J., and Pan, D. (2017). Surface chemistry of carbon nanoparticles functionally select their uptake in various stages of cancer cells. Nano Res. 10, 3269-3284. doi: 10.1007/s12274-017-1518-2

Stepien, G., Moros, M., Pérez-Hernández, M., Monge, M., Gutiérrez, L., Fratila, R. M., et al. (2018). Effect of surface chemistry and associated protein corona on the long-term biodegradation of iron oxide nanoparticles in vivo. ACS Appl. Mater. Interfaces 10, 4548-4560. doi: 10.1021/acsami.7b18648

Stern, S. T., Adiseshaiah, P. P., and Crist, R. M. (2012). Autophagy and lysosomal dysfunction as emerging mechanisms of nanomaterial toxicity. Particle Fibre Toxicol. 9:20. doi: 10.1186/1743-8977-9-20

Su, G., Jiang, H., Xu, B., Yu, Y., and Chen, X. (2018). Effects of protein corona on active and passive targeting of cyclic RGD peptidefunctionalized PEGylation nanoparticles. Mol. Pharmaceut. 15, 5019-5030. doi: 10.1021/acs.molpharmaceut.8b00612

Su, G., Zhou, H., Mu, Q., Zhang, Y., Li, L., Jiao, P., et al. (2012). Effective surface charge density determines the electrostatic attraction between nanoparticles and cells. J. Phys. Chem. C 116, 4993-4998. doi: 10.1021/jp211041m
Su, G., Zhou, X., Zhou, H., Li, Y., Zhang, X., Liu, Y., et al. (2016). Size-dependent facilitation of cancer cell targeting by proteins adsorbed on nanoparticles. ACS Appl. Mater. Interfaces 8, 30037-30047. doi: 10.1021/acsami.6b10967

Sun, H., Liu, Y., Bai, X., Zhou, X., Zhou, H., Liu, S., et al. (2018). Induction of oxidative stress and sensitization of cancer cells to paclitaxel by gold nanoparticles with different charge densities and hydrophobicities. J. Mater. Chem. B 6, 1633-1639. doi: 10.1039/C7TB03153J

Szegezdi, E., Logue, S. E., Gorman, A. M., and Samali, A. (2006). Mediators of endoplasmic reticulum stress-induced apoptosis. EMBO Rep. 7, 880-885. doi: 10.1038/sj.embor.7400779

Tedja, R., Soeriyadi, A. H., Whittaker, M. R., Lim, M., Marquis, C., Boyer, C., et al. (2012). Effect of $\mathrm{TiO} 2$ nanoparticle surface functionalization on protein adsorption, cellular uptake and cytotoxicity: the attachment of PEG comb polymers using catalytic chain transfer and thiol-ene chemistry. Polymer Chem. 3, 2743-2751. doi: 10.1039/c2py20450a

Untener, E. A., Comfort, K. K., Maurer, E. I., Grabinski, C. M., Comfort, D. A., and Hussain, S. M. (2013). Tannic acid coated gold nanorods demonstrate a distinctive form of endosomal uptake and unique distribution within cells. ACS Appl. Mater. Interfaces 5, 8366-8373. doi: 10.1021/am402848q

Van Haute, D., Liu, A. T., and Berlin, J. M. (2018). Coating metal nanoparticle surfaces with small organic molecules can reduce nonspecific cell uptake. ACS Nano 12, 117-127. doi: 10.1021/acsnano.7b03025

Vankayala, R., Kalluru, P., Tsai, H.-H., Chiang, C.-S., and Hwang, K. C. (2014). Effects of surface functionality of carbon nanomaterials on short-term cytotoxicity and embryonic development in zebrafish. J. Mater. Chem. B 2, 1038-1047. doi: 10.1039/C3TB21497D

Verma, A., and Stellacci, F. (2010). Effect of surface properties on nanoparticle-cell interactions. Small 6, 12-21. doi: 10.1002/smll.200901158

Walkey, C. D., Olsen, J. B., Guo, H., Emili, A., and Chan, W. C. (2012). Nanoparticle size and surface chemistry determine serum protein adsorption and macrophage uptake. J. Am. Chem. Soc. 134, 2139-2147. doi: $10.1021 /$ ja2084338

Wan, J., Wang, J.-H., Liu, T., Xie, Z., Yu, X.-F., and Li, W. (2015). Surface chemistry but not aspect ratio mediates the biological toxicity of gold nanorods in vitro and in vivo. Sci. Rep. 5:11398. doi: 10.1038/srep11398

Wang, S., Sun, H., Ang, H. M., and Tadé, M. O. (2013). Adsorptive remediation of environmental pollutants using novel graphene-based nanomaterials. Chem. Eng. J. 226, 336-347. doi: 10.1016/j.cej.2013.04.070

Wang, Z., Wang, C., Liu, S., He, W., Wang, L., Gan, J., et al. (2017). Specifically formed corona on silica nanoparticles enhances transforming growth factor $\beta 1$ activity in triggering lung fibrosis. ACS Nano 11, 1659-1672. doi: 10.1021/acsnano.6b07461

Wei, X., Shao, B., He, Z., Ye, T., Luo, M., Sang, Y., et al. (2015). Cationic nanocarriers induce cell necrosis through impairment of $\mathrm{Na}+/ \mathrm{K}+$-ATPase and cause subsequent inflammatory response. Cell Res. 25, 237-253. doi: 10.1038/cr.2015.9

Wu, L., Zhang, Y., Zhang, C., Cui, X., Zhai, S., Liu, Y., et al. (2014). Tuning cell autophagy by diversifying carbon nanotube surface chemistry. ACS Nano 8, 2087-2099. doi: 10.1021/nn500376w

Wydra, R. J., Rychahou, P. G., Evers, B. M., Anderson, K. W., Dziubla, T. D., and Hilt, J. Z. (2015). The role of ROS generation from magnetic nanoparticles in an alternating magnetic field on cytotoxicity. Acta Biomater. 25, 284-290. doi: 10.1016/j.actbio.2015.06.037

Xia, T., Kovochich, M., Brant, J., Hotze, M., Sempf, J., Oberley, T., et al. (2006). Comparison of the abilities of ambient and manufactured nanoparticles to induce cellular toxicity according to an oxidative stress paradigm. Nano Lett. 6, 1794-1807. doi: 10.1021/nl061025k

Xia, T., Kovochich, M., Liong, M., Mädler, L., Gilbert, B., Shi, H., et al. (2008). Comparison of the mechanism of toxicity of zinc oxide and cerium oxide nanoparticles based on dissolution and oxidative stress properties. ACS Nano 2, 2121-2134. doi: 10.1021/nn800511k

Xie, J., Wang, N., Dong, X., Wang, C., Du, Z., Mei, L., et al. (2019). Graphdiyne nanoparticles with high free radical scavenging activity for radiation protection. Acs Appl. Mater. Interfaces 11, 2579-2590. doi: 10.1021/acsami.8b00949

Xie, Y., Wan, B., Yang, Y., Cui, X., Xin, Y., and Guo, L.-H. (2019). Cytotoxicity and autophagy induction by graphene quantum dots with different functional groups. J. Environ. Sci. 77, 198-209. doi: 10.1016/j.jes.2018.07.014 
Xiong, Z., Zhao, L., Wang, F., Zhu, J., Qin, H., Wu, R., et al. (2012). Synthesis of branched PEG brushes hybrid hydrophilic magnetic nanoparticles for the selective enrichment of N-linked glycopeptides. Chem. Commun. 48, 8138-8140. doi: 10.1039/c2cc33600f

Yang, J. A., Lohse, S. E., and Murphy, C. J. (2014). Tuning cellular response to nanoparticles via surface chemistry and aggregation. Small 10, 1642-1651. doi: 10.1002/smll.201302835

Yin, H., Casey, P. S., Mccall, M. J., and Fenech, M. (2010). Effects of surface chemistry on cytotoxicity, genotoxicity, and the generation of reactive oxygen species induced by $\mathrm{ZnO}$ nanoparticles. Langmuir 26, 15399-15408. doi: 10.1021/la101033n

Yu, D., Zhang, Y., Zhou, X., Mao, Z., and Gao, C. (2012). Influence of surface coating of PLGA particles on the internalization and functions of human endothelial cells. Biomacromolecules 13, 3272-3282. doi: 10.1021/bm30 10484

Yu, Y., Duan, J., Yu, Y., Li, Y., Liu, X., Zhou, X., et al. (2014). Silica nanoparticles induce autophagy and autophagic cell death in HepG2 cells triggered by reactive oxygen species. J. Hazard. Mater. 270, 176-186. doi: 10.1016/j.jhazmat.2014.01.028

Zhang, T., Tang, M., Yao, Y., Ma, Y., and Pu, Y. (2019). MWCNT interactions with protein: surface-induced changes in protein adsorption and the impact of protein corona on cellular uptake and cytotoxicity. Int. J. Nanomed. 14, 993-1009. doi: 10.2147/IJN.S191689

Zhang, T., Tang, M., Zhang, S., Hu, Y., Li, H., Zhang, T., et al. (2017). Systemic and immunotoxicity of pristine and PEGylated multi-walled carbon nanotubes in an intravenous 28 days repeated dose toxicity study. Int. J. Nanomed. 12, 1539-1554. doi: 10.2147/IJN.S123345

Zhang, Y., Bai, Y., Jia, J., Gao, N., Li, Y., Zhang, R., et al. (2014). Perturbation of physiological systems by nanoparticles. Chem. Soc. Rev. 43, 3762-3809. doi: $10.1039 / \mathrm{C} 3 \mathrm{CS} 60338 \mathrm{E}$

Zhang, Y., Kohler, N., and Zhang, M. (2002). Surface modification of superparamagnetic magnetite nanoparticles and their intracellular uptake. Biomaterials 23, 1553-1561. doi: 10.1016/S0142-9612(01)00267-8
Zhang, Y., Pan, H., Zhang, P., Gao, N., Lin, Y., Luo, Z., et al. (2013). Functionalized quantum dots induce proinflammatory responses in vitro: the role of terminal functional group-associated endocytic pathways. Nanoscale 5, 5919-5929. doi: $10.1039 / \mathrm{c} 3 \mathrm{nr} 01653 \mathrm{f}$

Zhang, Y., Wang, Y., Liu, A., Xu, S. L., Zhao, B., Zhang, Y., et al. (2016). Modulation of carbon nanotubes' perturbation to the metabolic activity of CYP3A4 in the liver. Adv. Func. Mater. 26, 841-850. doi: 10.1002/adfm.201504182

Zhang, Y., Zhang, W., Fedutik, Y., Mao, Z., and Gao, C. (2019). Nanodiamonds of different surface chemistry influence the toxicity and differentiation of rat bone mesenchymal stem cells in vitro. J. Nanosci. Nanotechnol. 19, 5426-5434. doi: 10.1166/jnn.2019.16545

Zhou, H., Jiao, P., Yang, L., Li, X., and Yan, B. (2011). Enhancing cell recognition by scrutinizing cell surfaces with a nanoparticle array. J. Am. Chem. Soc. 133, 680-682. doi: 10.1021/ja108527y

Zhou, H., Mu, Q., Gao, N., Liu, A., Xing, Y., Gao, S., et al. (2008). A nanocombinatorial library strategy for the discovery of nanotubes with reduced protein-binding, cytotoxicity, and immune response. Nano Lett. 8, 859-865. doi: $10.1021 /$ nl0730155

Zhu, M., Nie, G., Meng, H., Xia, T., Nel, A., and Zhao, Y. (2013). Physicochemical properties determine nanomaterial cellular uptake, transport, and fate. Accounts Chem. Res. 46, 622-631. doi: 10.1021/ar300031y

Conflict of Interest: The authors declare that the research was conducted in the absence of any commercial or financial relationships that could be construed as a potential conflict of interest.

Copyright (C) 2019 Sun, Jiang, Wu, Bai and Zhai. This is an open-access article distributed under the terms of the Creative Commons Attribution License (CC BY). The use, distribution or reproduction in other forums is permitted, provided the original author(s) and the copyright owner(s) are credited and that the original publication in this journal is cited, in accordance with accepted academic practice. No use, distribution or reproduction is permitted which does not comply with these terms. 